\title{
Reduction of meckelin leads to general loss of cilia, ciliary microtubule misalignment and distorted cell surface organization
}

\author{
Tyler Picariello ${ }^{\dagger}$, Megan Smith Valentine ${ }^{\dagger}$, Junji Yano and Judith Van Houten ${ }^{*}$
}

\begin{abstract}
Background: Meckelin (MKS3), a conserved protein linked to Meckel Syndrome, assists in the migration of centrioles to the cell surface for ciliogenesis. We explored for additional functions of MKS3p using RNA interference (RNAi) and expression of FLAG epitope tagged protein in the ciliated protozoan Paramecium tetraurelia. This cell has a highly organized cell surface with thousands of cilia and basal bodies that are grouped into one or two basal body units delineated by ridges. The highly systematized nature of the $P$. tetraurelia cell surface provides a research model of MKS and other ciliopathies where changes in ciliary structure, subcellular organization and overall arrangement of the cell surface can be easily observed. We used cells reduced in IFT88 for comparison, as the involvement of this gene's product with cilia maintenance and growth is well understood.

Results: FLAG-MKS3p was found above the plane of the distal basal body in the transition zone. Approximately 95\% of those basal bodies observed had staining for FLAG-MKS3. The RNAi phenotype for MKS3 depleted cells included global shortening and loss of cilia. Basal body structure appeared unaffected. On the dorsal surface, the basal bodies and their associated rootlets appeared rotated out of alignment from the normal anterior-posterior rows. Likewise, cortical units were abnormal in shape and out of alignment from normal rows. A GST pull down using the MKS3 coiled-coil domain suggests previously unidentified interacting partners.

Conclusions: Reduction of MKS3p shows that this protein affects development and maintenance of cilia over the entire cell surface. Reduction of MKS3p is most visible on the dorsal surface. The anterior basal body is attached to and moves along the striated rootlet of the posterior basal body in preparation for duplication. We propose that with reduced MKS3p, this attachment and guidance of the basal body is lost. The basal body veers off course, causing basal body rows to be misaligned and units to be misshapen. Rootlets form normally on these misaligned basal bodies but are rotated out of their correct orientation. Our hypothesis is further supported by the identification of novel interacting partners of MKS3p including a kinetodesmal fiber protein, KdB2.
\end{abstract}

\section{Background}

Ciliopathies are human disorders caused by abnormalities in the assembly, maintenance or function of cilia and include developmental defects leading to cystic kidneys, vision problems, polydactyly, obesity, encephalocele and even death [1]. In order to improve our understanding of the wide array of cellular processes affected in these disorders, the function and involvement of the genes and gene

\footnotetext{
*Correspondence: Judith.Vanhouten@uvm.edu

${ }^{\dagger}$ Equal contributors

Department of Biology, University of Vermont, 120A Marsh Life Science Bldg, Burlington, VT 05405, USA
}

\section{Biomed Central

products involved in ciliopathies should be defined [2-4]. Toward this end, we have investigated the Meckel syndrome type 3 protein (MKS3) in Paramecium tetraurelia, a multiciliated cell.

MKS3 is one of at least three genes commonly associated with the ciliopathy Meckel syndrome (MKS), and has been found to be dysfunctional in other ciliopathy syndromes, including Bardet-Biedl syndrome [5]; cerebellar vermis hypoplasia/aplasia, oligophrenia, ataxia, coloboma and hepatic fibrosis, also known as $\mathrm{COACH}$ syndrome [6,7]; and Joubert syndrome [8]. The three most common characteristics of MKS are renal dysplasia, encephalocele and polydactyly $[9,10]$. The MKS disease is autosomal 
recessive and has high occurrence rates in Finland, the Middle East, North Africa and Asia [9-12].

Recently, it was shown that MKS3 is a component of a multiprotein complex that contributes to the function of the transition zone to separate the ciliary compartment from the rest of the cell [13]. Other cellular disruptions caused by a reduction of MKS3 have not been closely examined, such as changes in the subsurface scaffolding or in cell surface polarity and surface organization.

$P$. tetraurelia have large numbers of cilia and basal bodies arranged in polarized rows of hexagonal cortical units whose shape is created by a ridge of surface membrane covering an outer lattice. Each cortical unit contains one or two basal bodies. There is one cilium in each of these polarized cortical units (even in units with two basal bodies), as well as one parasomal sac (site of endo- and exocytosis) [14-16], and secretory vesicles (trichocysts) at the apex of the ridges [17-19]. Basal bodies have rootlets emanating from them in a stereotypical orientation relative to the anterior-posterior axis of the cell. The rootlets most likely help secure basal bodies and distribute the forces generated by the beating cilia $[20,21]$. Units with one basal body have a striated rootlet coursing anteriorly and a transverse and postciliary rootlet projecting in the 5 and 7 o'clock directions, respectively. In units with two basal bodies, the posterior basal body has a cilium and all three rootlets, and the anterior basal body has no cilium and only a transverse microtubule $[19,21]$.

The division process in Paramecium is complex and begins with basal body duplication. As the cell elongates, it accommodates for new basal bodies and cilia. The organization of the cortical units and their contents are determined by the "old," already existing units [22]. Disrupting this organization or development of these cortical units causes growth arrest and even cell death $[19,23,24]$. It is this highly repetitive patterned surface organization that allows identification of subtle changes in ciliary and surface organization in P. tetraurelia.

The results of epitope tagging and RNA interference (RNAi) to perturb the ciliopathy protein MKS3 in P. tetraurelia presented herein suggest previously unidentified roles for this protein in maintaining the cell and ciliary membrane surface and cytoskeletal organization. Tagged MKS3 protein is consistently found above the plane of the basal body, in the transition zone of Paramecium, which spans from the proximal surface of the epiplasm to the ciliary necklace [25,26]. Dawe and others [27] have published observations of short and missing cilia upon reduction of $M K S 3$ mRNA levels, which are similar to our findings of short and missing cilia with RNAi. Our study shows new findings, most notably that reduction of MKS3 causes misalignment of longitudinal rows of basal bodies, rotation of the orientation of basal bodies with their microtubule rootlets and distortion of the cell and ciliary surfaces. We also have evidence of new potential interacting partners of MKS3 relevant to these microtubule rootlets, suggesting important interactions of MKS3 with these structures. The depletion of intraflagellar transport 88 (IFT88) mRNA, used as a control to observe global ciliary loss, causes short and missing cilia but does not cause disarray of basal body rows or of the cell surface. We propose that MKS3p in Paramecium acts as a transient guide in the movement of basal bodies prior to duplication through an interaction with the microtubule rootlet system and that its localization at the base of the cilium is consistent with an involvement at the transition zone as a filter.

\section{Methods}

\section{Stocks, cultures and chemicals}

Cells (stock 51s P. tetraurelia, sensitive to killer) were grown in wheat grass medium inoculated with Klebsiella pneumoniae or Aerobacter aerogenes (adapted from [28]). All chemicals were obtained from Sigma-Aldrich (St Louis, MO, USA) unless otherwise noted.

\section{Sequence analysis and construct design}

BLAST searches in the Paramecium annotated genome were completed using the human sequence for TMEM67 (Q5HYA8) for MKS3 and the human IFT88 (NP_783195) and mouse $\operatorname{Tg} 737$ (NP_033402) sequences for IFT88 orthologs. Searches identified GSPATG00015939001 as a potential ortholog for $M K S 3$, which was used to create the RNAi construct. Five potential orthologs (GSPATG000385 05001, GSPATG00021390001, GSPATG00011771001, GSP ATG00022644001 and GSPATG00039556001) were identified for IFT88. The construct to target IFT88 mRNA was designed from GSPATG00038505001. Homology of these genes to those in other organisms is shown in Additional file 1: Tables S1 and S2.

All constructs were created from genomic DNA, which was collected by organic extraction. Briefly, $100 \mu \mathrm{l}$ of cells were mixed 1:1 with denaturing buffer (Promega, Madison, WI, USA), mixed 1:1 with phenol:chloroform: isoamyl alcohol (25:24:1) and centrifuged for 5 minutes at $12,000 \times g$ (Centrifuge 5424; Eppendorf, Hauppauge, NY, USA). The aqueous phase was removed, mixed 1:1 with chloroform:isoamyl alcohol (24:1) and spun again. The DNA was precipitated 2:1 with cold isopropanol for 20 minutes at $-20^{\circ} \mathrm{C}$ and spun for 10 minutes at $4^{\circ} \mathrm{C}$ (Centrifuge 5424). Pellets were rinsed twice with $75 \%$ ethanol, dried and resuspended in water.

\section{FLAG-tag of $M K S 3$}

To localize MKS3p, we added the coding sequence for a threefold repeated FLAG sequence (DYKDDDDK) to the 5 ' end of the genomic DNA sequence for GSPATG000 
15939001 in the pPXV plasmid using the restriction enzymes ApaI and SacI (USB/Affymetrix, Cleveland, OH, USA). These cut sites were created using large primers to add them to either end of the sequence: forward ( $5^{\prime}$ gcggggcccatgctaatttatatcg- $\left.3^{\prime}\right)$ and reverse (5'-cgcgagctct catattagaaaccttttgtc-3'). PlatinumPfx Polymerase (Invitrogen/Life Technologies, Grand Island, NY, USA) was used per the vendor's instructions to amplify the sequence. A total of $75 \mathrm{ng}$ of genomic DNA was used in each PCR: $94^{\circ} \mathrm{C}$ for 5 minutes; five cycles of $94^{\circ} \mathrm{C}$ for 1 minute, $40^{\circ} \mathrm{C}$ for 1 minute and $68^{\circ} \mathrm{C}$ for 3 minutes; five cycles of $94^{\circ} \mathrm{C}$ for 1 minute, $48^{\circ} \mathrm{C}$ for 1 minute and $68^{\circ} \mathrm{C}$ for 3 minutes; ten cycles of $94^{\circ} \mathrm{C}$ for 1 minute, $58^{\circ} \mathrm{C}$ for 1 minute and $68^{\circ} \mathrm{C}$ for 3 minutes; seventeen cycles of $94^{\circ} \mathrm{C}$ for 1 minute, $65^{\circ} \mathrm{C}$ for 1 minute and $68^{\circ} \mathrm{C}$ for 3 minutes; and one cycle of $68^{\circ} \mathrm{C}$ for 15 minutes (Techne TC-4000 Thermal Cycler; Krackeler Scientific, Albany, NY, USA). The products were cleaned using the PrepEasy Gel Extraction Kit (Affymetrix). The resulting DNA was treated with restriction enzymes, cleaned again using the PrepEasy Gel Extraction Kit and ligated into the pPXV-5' $-3 x$ FLAG plasmid using the Ligate-IT Kit (Affymetrix). The mixture was then transformed into OneShot competent cells (Invitrogen/Life Technologies), and the resulting colonies were screened for positives. Positive clones were sequenced at the Vermont Cancer Center DNA Analysis Facility (University of Vermont, Burlington, VT, USA).

\section{Plasmid injection}

Approximately $200 \mu \mathrm{g}$ of pPXV-3xFLAG-MKS3 was linearized with NotI (Affymetrix) overnight at $37^{\circ} \mathrm{C}$ and then cleansed using an organic extraction method modified from that described earlier. This procedure required two washes in phenol:chloroform:isoamyl alcohol (25:24:1) followed by two washes of chloroform:isoamyl alcohol (24:1). The final pellet was resuspended in $50 \mu \mathrm{l}$ of MilliQ water (EMD Millipore, Billerica, MA, USA), and the concentration was checked using a spectrophotometer (Agilent Technologies, Santa Clara, CA, USA). The sample was spun at 16,000 $\times g$ (Eppendorf Centrifuge 5424) for 10 minutes to pellet debris. The top $45 \mu \mathrm{l}$ was carefully removed and placed in a fresh RNase/DNase-free 1.5-ml Eppendorf tube and again dried in a speed vac. The final pellet was resuspended in MilliQ water to obtain a concentration between 3 and $9 \mu \mathrm{g} / \mu \mathrm{l}$ and stored at $4^{\circ} \mathrm{C}$ until injection.

Approximately 20 cells which had recently undergone autogamy were placed under high-temperature silicon oil to immobilize them. Approximately 5 to $50 \mathrm{pg}$ of the plasmid was injected into the macronucleus of each cell using a pulled capillary and a Narishige micromanipulator (Narishige International USA, East Meadow, NY, USA). Individual injected cells were transferred to $750 \mu \mathrm{l}$ of inoculated culture fluid in depression slides and incubated in a humidifying chamber at RT for 2 days, allowing the cells to recover and divide. Cells were then transferred to test tubes with inoculated culture fluid and maintained at $15^{\circ} \mathrm{C}$ as individual clones. Genomic DNA was extracted from the clone cultures as described previously (see Sequence analysis and construct design text section) and tested by PCR using plasmid-specific primers: the forward primer for the plasmid pPXV (5'taagatgaatggaatataatg- $\left.3^{\prime}\right)$ and a reverse primer ( $5^{\prime}$-gaaaa cccaagccaatcaatac-3'), which was sequence-specific for MKS3. DNA ( $1 \mu \mathrm{l}$, approximately $400 \mathrm{ng}$ ) was used in each PCR: one cycle at $95^{\circ} \mathrm{C}$ for 5 minutes followed by 30 cycles at $95^{\circ} \mathrm{C}$ for 1 minute, $40^{\circ} \mathrm{C}$ for 1 minute and $72^{\circ} \mathrm{C}$ for 3 minutes followed by one 15 -minute cycle at $72^{\circ} \mathrm{C}$.

\section{Localization, visualization and analysis of FLAG-MKS3p}

We tested small cultures of individual clones to ascertain whether the cells expressed the protein and where it was localized. A 10-ml culture of injected cells was added to $50 \mathrm{ml}$ of inoculated culture fluid and grown at $22^{\circ} \mathrm{C}$ for approximately 48 to 72 hours. The cells were immunostained and imaged as described below. Images were analyzed for colocalization using softWoRx Pro software (Applied Precision, Issaquah, WA, USA). Experiments were repeated five times.

To isolate pellicle membrane and whole cilia membrane, wild-type (stock 51s P. tetraurelia) cells expressing FLAG (control) or FLAG-MKS3 (Test) were maintained in large cultures ( 3 to $6 \mathrm{~L}$ of culture fluid) at $22^{\circ} \mathrm{C}$ until a density of 8,000 to 12,000 cells $/ \mathrm{ml}$ was achieved. For pellicular membrane, cells were harvested as described previously [29]. In separate experiments, cilia were separated from cell bodies and collected as previously described [30] up to the point of separation of the ciliary membrane from the axoneme. Protein concentrations were determined using a bicinchoninic acid protein assay (Thermo Scientific, Pittsburgh, PA, USA) and equalized between the test and control. Samples were separated on a $12 \%$ SDSPAGE gel after adding $1 \mu \mathrm{l}$ of $\beta$-mercaptoethanol and boiling for 5 minutes. One hundred micrograms of pure pellicular membrane and $400 \mu \mathrm{g}$ of whole cilia were loaded, along with $10 \mu \mathrm{l}$ of a Pierce Biotechnology threecolor prestained protein molecular weight marker (Thermo Scientific). Proteins were transferred onto nitrocellulose membrane (Pall Gelman Versapor; Krackeler Scientific, Albany, NY, USA) and blocked for 1 hour using 5\% nonfat dry milk, 2\% Telost gelatin from fish, 3\% normal goat serum (Vector Laboratories, Burlingame, CA, USA), in Tris-buffered saline Tween 20 (TBS-T) (15 mM Tris-Cl, $140 \mathrm{mM} \mathrm{NaCl}, 0.1 \% \mathrm{v} / \mathrm{v}$ Tween 20, pH 7.5). Blots were probed with a 1:2,500 dilution of rabbit Anti-FLAG M2 clone or 1:10,000 mouse anti-tubulin in the blocking buffer. Blots were incubated overnight while rocking at $4^{\circ} \mathrm{C}$. Buffers were removed, the blots were rinsed three 
times in TBS-T and then incubated for $1 \mathrm{~h}$ in 1:10,000 goat anti-rabbit or anti-mouse alkaline phosphatase (AP)-conjugated secondary antibody. Blots were rinsed again four times in TBS-T for 15 minutes for each wash and developed using nitroblue tetrazolium/5-bromo-4chloro-3'-indolyl phosphate AP (Moss, Inc, Pasadena, MD, USA).

\section{RNAi by feeding construct}

Constructs for RNAi were created from genomic DNA using the following primers: $M K S 3$ forward, $5^{\prime}$-gaaaaccc aagccaatcaatac- 3 ' and reverse, $5^{\prime}$-ggtcgacaatctgaaggataag$3^{\prime}$; and IFT88 forward, 5' -caattaaggaaaaccacctg-3' and reverse, $5^{\prime}$-aaaactaacaggattgtcatct-3'. All PCR conditions began with an initial step at $95^{\circ} \mathrm{C}$ for 5 minutes and ended with a final stage at $72^{\circ} \mathrm{C}$ for 20 minutes. The MKS3 RNAi construct was amplified by 30 cycles at $95^{\circ} \mathrm{C}$ for 1 minute, $52^{\circ} \mathrm{C}$ for 1 minute and $72^{\circ} \mathrm{C}$ for 2 minutes. The IFT 88 construct was amplified by five cycles at $95^{\circ} \mathrm{C}$ for 1 minute, $47^{\circ} \mathrm{C}$ for 1 minute and $72^{\circ} \mathrm{C}$ for 2.25 minutes; followed by twenty-five cycles at $95^{\circ} \mathrm{C}$ for 1 minute, $50^{\circ} \mathrm{C}$ for 1 minute and $72^{\circ} \mathrm{C}$ for 2.25 minutes (Techne Thermal Cycler; Bibby Scientific, Burlington, NJ, USA). The final PCR products were analyzed on $0.75 \%$ or $1.0 \%$ agarose gel (Invitrogen/ Life Technologies) and visualized with ethidium bromide. Resulting PCR products were cloned directly into PCR2.1TOPO vector (Invitrogen/Life Technologies), transformed into OneShot cells (Invitrogen/Life Technologies), and sequenced. Correct sequences were cut from the pCR2.1TOPO vector and ligated into the double-T7 promoter vector L4440 (AddGene, Cambridge, MA, USA) using the Ligate-IT Kit (USB/Affymetrix) as per the kit instructions. Escherichia coli strain Ht115 (DE3), which lacks RNaseIII, was transformed with $50 \mathrm{ng}$ of plasmid DNA for either MKS3 or IFT88. As a control, Ht115 cells were transformed with L4440 with no insert. Bacterial cultures were maintained with tetracycline $(12.5 \mu \mathrm{g} / \mathrm{ml})$ and ampicillin (AMP) $(100 \mu \mathrm{g} / \mathrm{ml})$.

\section{RNAi by feeding}

Overnight cultures of Ht115(DE3) transformed with RNAi or control plasmids were used to inoculate $50 \mathrm{ml}$ of LB-AMP $(100 \mu \mathrm{g} / \mathrm{mL})$ and grown until the $595-\mathrm{nm}$ optical density reached 0.3 to 0.4 , at which point isopropyl $\beta$-D-1-thiogalactopyranoside (IPTG) (RPI, Mount Prospect, IL, USA) was added to a final concentration of $0.125 \mathrm{mg} / \mathrm{ml}$. Cultures were incubated with shaking for 3 hours at $37^{\circ} \mathrm{C}$ to induce the production of doublestranded RNA. Paramecia that had recently undergone autogamy were collected by centrifugation and resuspended in $10 \mathrm{ml}$ of Dryl's solution $\left(1 \mathrm{mM} \mathrm{Na}_{2} \mathrm{HPO}_{4}\right.$, $1 \mathrm{mM} \mathrm{NaH} \mathrm{PO}_{4}, 1.5 \mathrm{mM} \mathrm{CaCl}, 2 \mathrm{mM}$ Na-citrate, $\mathrm{pH}$ 6.8) to purge bacteria from their surfaces and food vacuoles.
The induced bacteria were collected by centrifugation at 4,000 $\times g$ (Beckman J2-21 centrifuge, JA-14 rotor; Beckman Coulter, Brea, CA, USA) at $4^{\circ} \mathrm{C}$ and resuspended in $100 \mathrm{~mL}$ of wheat culture medium containing an additional $8 \mu \mathrm{g} / \mathrm{mL}$ stigmasterol, $0.125 \mathrm{mg} / \mathrm{mL}$ IPTG (RPI), and $100 \mu \mathrm{g} / \mathrm{ml}$ AMP. Approximately 50 to 100 of the purged paramecia were added to the control culture. In the case of the MKS3 and IFT88 RNAi cultures, 4,000 and 8,000 cells were added to $100 \mathrm{ml}$, respectively. Cultures were maintained at $28^{\circ} \mathrm{C}$, and after 24 hours, an additional $0.125 \mathrm{mg} / \mathrm{ml}$ of IPTG (RPI) and $800 \mu \mathrm{g}$ of stigmasterol were added. Growth rates of cultures were determined by counting cells at 24, 48 and 72 hours of growth. All experiments were repeated a minimum of three time and all cultures were harvested or observed after approximately 72 hours of growth unless noted otherwise.

\section{Immunofluorescence}

Cultured cells $(100 \mathrm{ml})$ were collected by centrifugation (Damon IEC Division Clinical Centrifuge, Needham Heights, MA, USA) and rinsed twice in $100 \mathrm{ml}$ of Dryl's solution. The cell volume was reduced to approximately $100 \mu \mathrm{l}$ in a 1.5-ml Eppendorf tube before $1 \mathrm{ml}$ of PHEM and $0.1 \%$ or $0.5 \%$ Triton X-100) was added. Cells were undisturbed for 1 to 4 minutes, then spun at $250 \times g$ (Damon IEC Division Clinical Centrifuge) and then the supernatant was removed and the pellet (cells) was mixed with $1 \mathrm{ml}$ of fixation buffer (2\% or $4 \%$ paraformaldehyde (Electron Microscopy Sciences, Hatfield, PA, USA), $2 \mathrm{mM} \mathrm{NaH} \mathrm{PO}_{4} \bullet \mathrm{H}_{2} \mathrm{O}, 8 \mathrm{mM} \mathrm{Na} \mathrm{HPO}_{4}, 150 \mathrm{mM}$ $\mathrm{NaCl}, \mathrm{pH}$ 7.5). Samples were undisturbed for 10 minutes or rocked for 1 hour at room temperature (RT) and washed three times in $1 \mathrm{ml}$ of blocking buffer $(2 \mathrm{mM}$ $\mathrm{NaH}_{2} \mathrm{PO}_{4} \cdot \mathrm{H}_{2} \mathrm{O}, 8 \mathrm{mM} \mathrm{Na}_{2} \mathrm{HPO}_{4}, 150 \mathrm{mM} \mathrm{NaCl}$, $10 \mathrm{mM}$ EGTA, $2 \mathrm{mM} \mathrm{MgCl} 2,0.1 \%$ Tween $20,1 \%$ or $3 \%$ bovine serum albumin (BSA), $\mathrm{pH} 7.5$ ).

Primary antibodies for the immunostaining for localization were as follows: FLAG-MKS3: mouse anti-FLAG, M2 clone at a 1:300 dilution (Sigma-Aldrich) and anticentrin at a 1:1,000 dilution (anti-Tetrahymena centrin, gift from Mark Winey, University of Colorado, Boulder, CO, USA). For ciliary measurements, we used mouse anti- $\alpha$-tubulin at a dilution of 1:200 (Sigma-Aldrich). For visualization of basal bodies, we used anti-centrin at a dilution of 1:1,000. For cortical unit visualization, we used anti-2F12 at a dilution of 1:200 (gift from Jean Cohen, Gif-sur-Yvette, France). For the visualization of the kinetodesmal fibers (KDFs), we used anti-KDF at a 1:400 dilution (gift from Janine Beisson, Centre de Génétique Moléculaire, Gif-sur-Yvette, France) and antiGlu- $\alpha$-tubulin at a 1:500 dilution (Synaptic Systems, Göttingen, Germany). Primary antibodies in $100 \mu \mathrm{l}$ of blocking buffer were mixed with the cells and rocked at 
RT for 1 hour. Cells were washed three times in blocking buffer or wash buffer $\left(2 \mathrm{mM} \mathrm{NaH} \mathrm{PO}_{4} \cdot \mathrm{H}_{2} \mathrm{O}, 8 \mathrm{mM}\right.$ $\mathrm{Na}_{2} \mathrm{HPO}_{4}, 150 \mathrm{mM} \mathrm{NaCl}, 0.1 \%$ Tween 20, 1\% BSA, $\mathrm{pH}$ 7.5). The cells were mixed with $100 \mu \mathrm{l}$ of blocking buffer with a 1:200 dilution of secondary antibodies. Secondary antibodies (Molecular Probes/Invitrogen, Grand Island, NY, USA) included Alexa Fluor 488 or 555 goat anti-mouse and Alexa Fluor 488 or 568 goat anti-rabbit. After 30 minutes to 1 hour of incubation while rocking, cells were washed three to five times with blocking or wash buffer and, to the final $20 \mu \mathrm{l}$ of cells, one drop (approximately $15 \mu \mathrm{l}$ ) of VECTASHIELD mounting medium (Vector Laboratories, Burlingame, CA, USA) was added. Tubes were wrapped in aluminum foil and stored at $4{ }^{\circ} \mathrm{C}$ until use.

Imaging of the immunostained cells was done using a DeltaVision Restoration Microscopy System (Applied Precision), consisting of an inverted Olympus IX70 microscope (Olympus America, Center Valley, PA, USA) and a Kodak CH350E camera (Rochester, NY, USA). Prepared cells $(7 \mu \mathrm{l})$ were placed under a glass coverslip and imaged at $20^{\circ} \mathrm{C}$ to $22^{\circ} \mathrm{C}$ using either a PlanApo $60 \times$ or $100 \times / 1.40$ oil-immersion lens objective and deconvolved and analyzed using softWoRx Pro software.

Colocalization of FLAG-MKS3 and centrin (basal bodies) was analyzed using softWoRx Pro software or ImageJ software [31]. Eleven cells were analyzed for the colocalization of these two proteins. To examine the staining patterns and calculate the number of basal bodies with FLAG-MKS3 staining, $15 \mu \mathrm{m} \times 15 \mu \mathrm{m}$ grids were chosen from both the ventral and dorsal surfaces of each of three cells. Basal bodies within that grid were counted, and we noted whether they had FLAG-MKS3 staining. A total of 463 basal bodies were analyzed on these three cells.

\section{Scanning electron microscopy}

RNAi cultured cells $(200 \mathrm{ml})$ were collected by brief centrifugation at $800 \times g$ (Damon IEC Division Clinical Centrifuge), washed twice in Dryl's solution and fixed as described by Lieberman et al. [32]. After critical point drying, coverslips were glued onto an aluminum chuck using colloidal graphite cement and allowed to dry in a desiccator overnight. The samples were sputter-coated and stored in a desiccator until imaged using a JSM-6060 scanning electron microscope (JEOL USA, Peabody, MA, USA).

\section{Transmission electron microscopy}

RNAi cultured cells $(100 \mathrm{ml})$ were collected by brief centrifugation at $800 \times g$ (Damon IEC Division Clinical Centrifuge) and washed twice in $100 \mathrm{ml}$ of Dryl's solution, then approximately $100 \mu \mathrm{L}$ of the cell pellet was removed and placed in 1.5-ml Eppendorf tubes. One milliliter of Fixation Solution A (1\% gluteraldehyde (Electron
Microscopy Sciences), 0.05 M sodium cacodylate, $\mathrm{pH}$ 7.2) was added, rocked for 30 minutes on ice and washed three times for 10 minutes under the same conditions. Cells were resuspended in postfix Solution B (1\% gluteraldehyde (Electron Microscopy Sciences), $0.05 \mathrm{M}$ sodium cacodylate buffer, $1 \%$ osmium tetroxide, $\mathrm{pH}$ 7.2) and again washed and rinsed as described above. Cells were preembedded in $2 \%$ agarose gel (Invitrogen/Life Technologies) in $0.05 \mathrm{M}$ sodium cacodylate buffer and allowed to set, then sliced into $1 \mathrm{~mm} \times 1 \mathrm{~mm}$ blocks. Blocks were placed in glass vials with $50 \%$ ethanol and rocked on a specimen rotator for 30 minutes during each of the following washes: ethanol at concentrations of $50 \%, 70 \%$ and $90 \%$ and two times at $100 \%$, with both of the latter in propylene oxide. Cells were left overnight on a specimen rotator in 1:1 propylene oxide and Spurr's solution (Electron Microscopy Sciences). The next day, samples were placed in fresh Spurr's solution for 6 hours and placed in flat embedding molds with fresh Spurr's solution at $60^{\circ} \mathrm{C}$ for 48 hours. Sections were cut to $90-\mathrm{nm}$ thickness, placed on copper 200 -mesh grids and contrasted on droplets of $2 \%$ uranyl acetate in $50 \%$ ethanol for 6 minutes followed by lead citrate $(120 \mathrm{mM}$ sodium citrate, $2.66 \%$ lead nitrate and $0.65 \%$ sodium hydroxide in water) for 4 minutes. Sections were imaged using a JEM-1210 electron microscope (JEOL USA). These studies were repeated three times.

\section{Glutathione S-transferase pull-down and mass spectrometry analysis}

The coiled-coil domain of MKS3 was expressed with a glutathione $S$-transferase (GST) tag for use in a GST pull-down assay. The construct was created by amplifying positions $+2,183$ to $+2,273$ of GSPATG00015939001 using the following forward and reverse primers, respectively: $5^{\prime}$-gcgggatccatgaattttgtcgatctc- $3^{\prime}$ and $5^{\prime}$ gcggaattctgatggatttctccatg-3'. The PCR product was treated with BamHI and EcoRI restriction enzymes (New England Biolabs, Ipswich, MA, USA) and cleaned using gel purification and the PrepEase Gel Extraction Kit (Affymetrix, Santa Clara, CA, USA), then ligated into a pGEX-2TK plasmid vector (GE Healthcare Life Sciences, Pittsburgh, PA, USA) using the Ligate-IT Rapid Ligation Kit (Affymetrix). The pGEX-2TK plasmid vector had already been opened using the same restriction enzymes, treated with $1 \mathrm{U}$ of calf intestinal alkaline phosphatase at $37^{\circ} \mathrm{C}$ for 5 minutes to remove the phosphate groups, followed by heat inactivation with $5 \mathrm{mM} \mathrm{Na} \mathrm{Na}_{2}$-ethylenediaminetetraacetic acid at $72^{\circ} \mathrm{C}$ for 20 minutes. The GST-MKS3 coiled-coil domain and GST were expressed in BL-21 cells and bound to glutathione sepharose beads (GE Healthcare Life Sciences) as described previously [33]. After beads were 
collected from bacterial cell lysates, they were washed in a $1 \mathrm{M} \mathrm{MgCl}_{2}$ buffer to remove bacterial proteins from the GST and GST-MKS3 proteins. Proteinbound beads were stored at $4^{\circ} \mathrm{C}$ in phosphatebuffered saline for up to 2 weeks.

Stock $51 \mathrm{~s} P$. tetraurelia cells were cultured and harvested as described previously [34] for whole-cell extract (WCE). Glutathione sepharose beads (GE Healthcare Life Sciences) were prepared by washing three times in LAP200 buffer $(50 \mathrm{mM}$ HEPES, $200 \mathrm{mM} \mathrm{KCl}, 1 \mathrm{mM}$ EGTA, $1 \mathrm{mM} \mathrm{MgCl}_{2}, \mathrm{pH}$ 7.4) buffer with $1 \%$ Triton X-100. Washed beads $(200 \mu \mathrm{l})$ were added to $20 \mathrm{ml}$ of WCE. This precleared WCE was then split in half and incubated with $200 \mu \mathrm{l}$ of glutathione sepharose beads attached to either GST or GST-MKS3. Beads in the supernatant were allowed to rock on ice at $4^{\circ} \mathrm{C}$ for 1 hour. Control and test beads were recovered and washed three times in LAP200 buffer with $1 \%$ Triton X-100. Samples were run on a $7 \%$ to $14 \%$ gradient acrylamide gel and silver-stained, then gel slices were trypsin-digested as described previously [34].

Samples were analyzed by liquid chromatographytandem mass spectrometry (LC-MS/MS) on a linear ion trap LTQ XL Linear Ion Trap Mass Spectrometer (Thermo Fisher Scientific, Asheville, NC, USA). Half the material was loaded onto a $100-\mu \mathrm{m} \times 120 \mathrm{~mm}$ capillary column packed with MAGIC C18 $(5-\mu \mathrm{m}$ particle size, 20-nm pore size; Michrom Bioresources, Auburn, CA, USA) at a flow rate of $500 \mathrm{nl} / \mathrm{min}$. Peptides were separated by a gradient of $5 \%$ to $35 \%$ $\mathrm{CH}_{3} \mathrm{CN} / 0.1 \%$ formic acid for 30 minutes, $40 \%$ to $100 \% \mathrm{CH}_{3} \mathrm{CN} / 0.1 \%$ formic acid for 1 minute and $100 \% \mathrm{CH}_{3} \mathrm{CN}$ for 10 minutes.

Product ion spectra were searched using the SEQUEST search engine on Proteome Discoverer 1.4 (Thermo Fisher Scientific) against a curated P. tetraurelia database with sequences in forward and reverse orientations. The 13 raw files from control samples and the 13 raw files from test samples were searched as one contiguous input file, and a single result file was generated for each. The database was indexed to allow for full trypsin enzymatic activity, two missed cleavages and peptides between the molecular weights of 350 to 5,000 $\mathrm{Da}$. Search parameters set the mass tolerance at $2 \mathrm{Da}$ for precursor ions and $0.8 \mathrm{Da}$ for fragment ions. The result files were then searched against Scaffold version 4.0.5 software (Proteome Software, Portland, OR, USA). Crosscorrelation (xcorr) significance filters were applied to limit the false-positive rates to less than $1 \%$ in both data sets. The xcorr values were as follows: $(+1): 1.8,(+2): 2.7$, $(+3): 3.3$ and $(+4): 3.5$. Other filters applied were a minimum peptide cutoff of 2 as well as DeltaCN $>0.1$. Ultimately, the confidence parameters resulted in $0 \%$ false discovery rate at the protein and peptide level for both the control and test results.

\section{Results}

\section{Sequence analysis}

The sequence for MKS3 in Paramecium (GSPATG0001 $5939001,4 \mathrm{e}^{-57}, 23 \%$ identity) was found using the human sequence for TMEM67 (Q5HYA8) and the annotated Paramecium genome (ParameciumDB, http://paramecium.cgm. cnrs-gifffr/). Paramecium MKS3 (TMEM67) codes for 2,906 nucleic acids and 951 amino acids. The RNAi construct design for Paramecium MKS3 comprises bases from positions $+1,101$ to $+2,019$.

Five potential homologues for IFT88 were found using the human IFT88 (NP_783195) and mouse Tg737 (NP 033402) sequences. The best match was GSPATP0003 8505001 ( $\mathrm{e}^{-146}, 38 \%$ identity), which codes for $2,341 \mathrm{nu}-$ cleic acids and 743 amino acids. The RNAi construct for Paramecium IFT88 spans positions +48 to $+2,121$. Using a feature of ParameciumDB to identify potential off-target effects [35], we found that the MKS3 RNAi plasmid will target only GSPATG00015939001, whereas the RNAi plasmid for IFT88 will target all five homologues but no other gene sequences outside this gene family. Included in the Supplemental Material are tables comparing Paramecium IFT88 and MKS3 (Additional file 1: Table S1 and Table S2) with sequences from other organisms. To further document the conservation of these proteins in Paramecium, amino acid alignments of full length and conserved regions in each protein are included in Additional file 2: Figure S1 and Additional file 3: Figure S2.

\section{FLAG-MKS3p immunostaining and localization}

We used a 5'-3xFLAG-tagged (FLAG-MKS3) expression vector to produce FLAG-MKS3p to localize the MKS3 protein. Control paramecia were derived from cells that were injected with the empty FLAG vector to confirm that cells were unaffected by the expressed FLAG peptide. Cells were permeabilized, stained with anti-centrin and anti-FLAG and imaged. In Figure 1, images are stacks to ensure that basal bodies and FLAG-MKS3p staining are visible. Cells expressing FLAG or FLAGMKS3 showed similar centrin staining patterns across the cell surface (Figure 1A). The control cells show almost no staining by anti-FLAG, but the FLAG-MKS3expressing cells show very clear FLAG staining near the basal bodies and faint staining in the cilia (Figure 1A and arrows in Figure 1C; see also Western blots of the tagged protein from cell membrane and cilia in Additional file 4: Figure S4). Additional file 5: Movie S1 demonstrates this pattern of FLAG-MKS3p staining above the staining of centrin. When scanning through the same cell, starting from the surface, the green FLAG staining can be seen prior to the red staining of the centrin. Figure $1 \mathrm{~B}$ also 


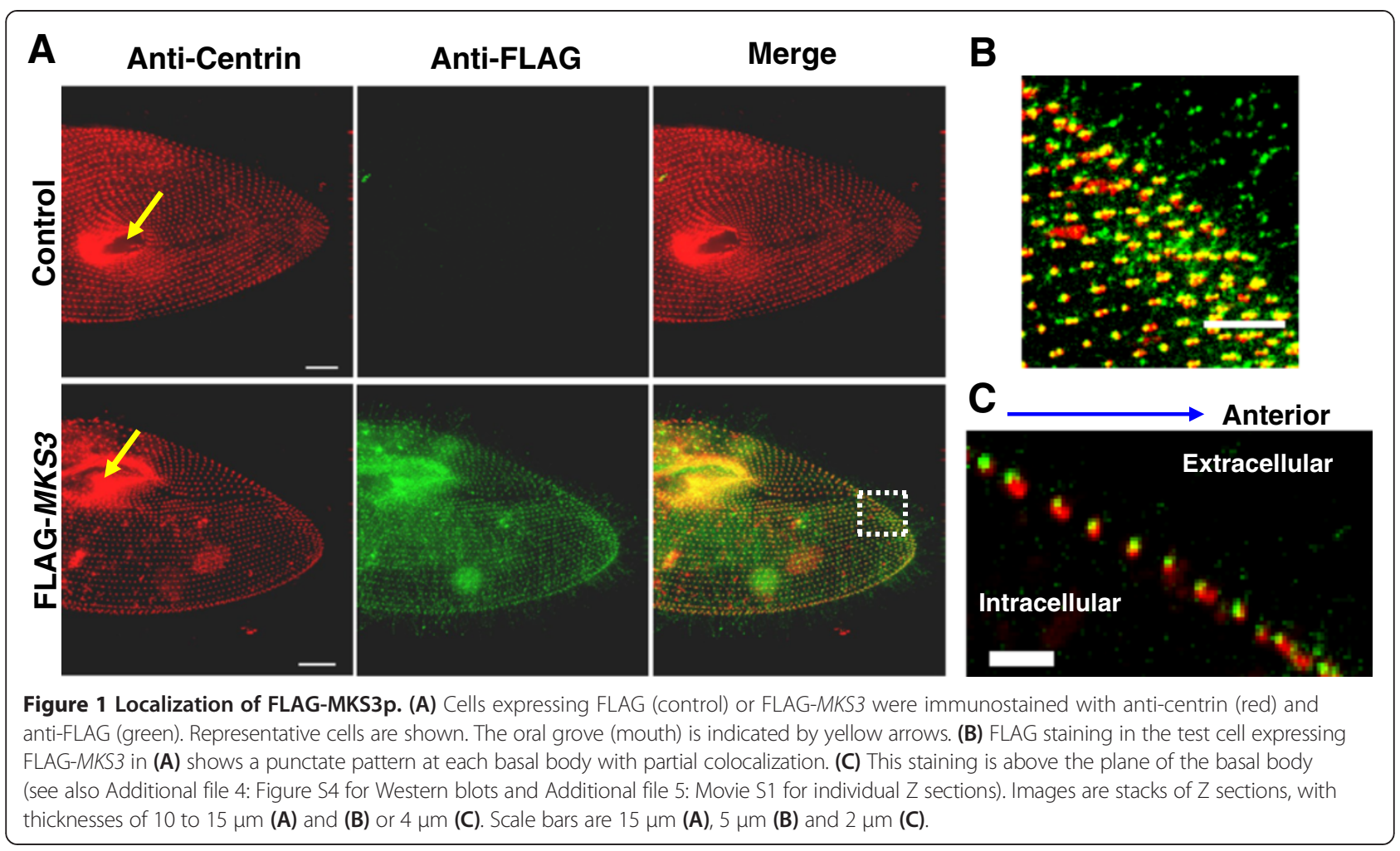

demonstrates the FLAG-MKS3p staining at the distal side of the centrin staining, that is, above the staining of the basal body. The anti-centrin antibody recognizes Tetrahymena centrin 1, which is homologous to Paramecium centrin 2, which is found in the basal body along the shaft [24]. The transition zone of the Paramecium cilium has been defined as stretching from the basal body, near the proximal surface of the epiplasm, to the base of the cilium, where the triplets of microtubules become doublets and the central pair of microtubule doublets begins $[25,26]$. The localization of the MKS3 protein is therefore consistent with that of the transition zone for these cells.

To quantify the basal body and FLAG-MKS3p staining, $15 \mu \mathrm{m} \times 15 \mu \mathrm{m}$ squares on the dorsal and ventral surfaces of three different cells expressing FLAG-MKS3 were randomly chosen. Of the 463 basal bodies observed, $95.2 \% \pm 2.2 \%$ of them had FLAG-MKS3 staining. These data suggest that where a basal body is present, we expect to find MKS3 protein. To quantify the extent of colocalization of the centrin and FLAG-MKS3p staining, the images were analyzed using softWoRx software to obtain a Pearson's coefficient $(r)$. Eleven FLAG-MKS3p cells showed an average colocalization score of $0.46 \pm 0.11(r \pm \mathrm{SD})$, indicating partial colocalization. FLAG-MKS3p staining is clearly seen in the oral groove (Figure 1A, yellow arrows), but we were unable to differentiate individual basal bodies in this region because of their close packing and the spatial limitations of fluorescence microscopy. Therefore, these oral groove basal bodies were not included in our analysis.

\section{Ultrastructure}

We utilize RNAi by feeding of paramecia because of its ease of use and because the creation of knockouts by homologous recombination is not possible. RNAi allows us to observe the cells in a depleted state of a targeted protein quickly and effectively in a wild-type background. RNAi is estimated to be $80 \%$ effective [36]. It allowed us to leave variable amounts of the targeted protein in the cells and thereby protect them from lethal effects of complete loss of MKS3. We found that very aggressive RNAi treatment quickly led to cell death. In this way, RNAi had an advantage over gene knockout.

Scanning electron micrographs (SEMs) show that the control cells were covered in cilia and display a highly organized cell surface with one cilium protruding from each cortical unit (Figures 2A and 2B). The cilia on the control cells appear normal, as shown in the representative cell in Figure 2A. The MKS3-depleted cells displayed very short and sparse cilia (Figures $2 \mathrm{C}$ to $2 \mathrm{~F}$ ) and look dramatically different from the controls. The cilia that are present do not resemble the control cilia. They have wrinkled surfaces and bulges at the tips (Figures $2 \mathrm{E}$ and 2F). Of the $23 M K S 3$-depleted cells observed, 56.5\% displayed the "blebby" cilia. This was not observed on 

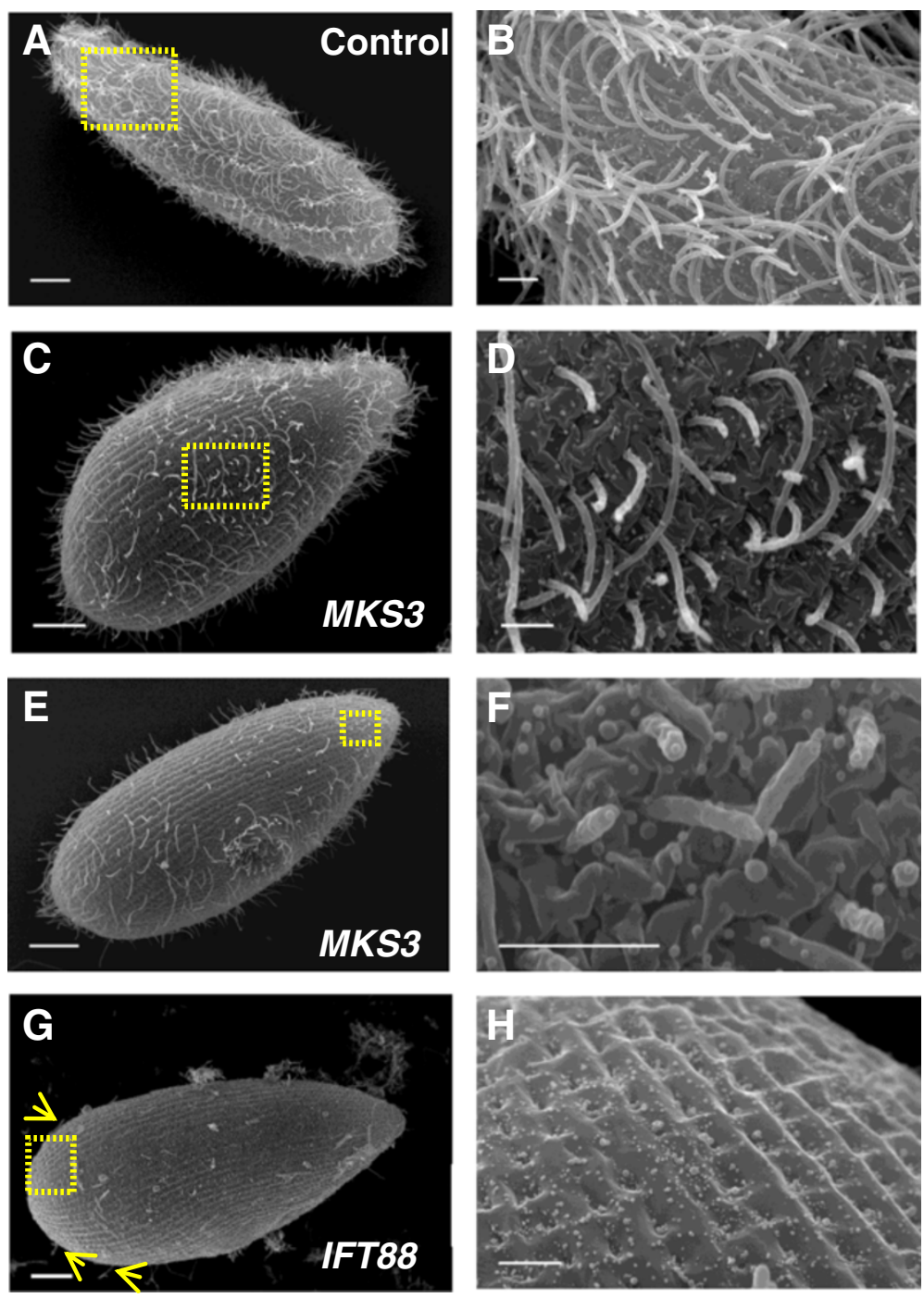

Figure 2 MKS3-depleted cells have sparse cilia and distorted cell and ciliary surfaces. Scanning electron micrographs of representative images of control (A) and (B), MKS3-depleted (C) through (F) and IFT88-depleted (G) and (H) cell populations. The cell in (G) has been rotated. Whole-cell images of control (A), MKS3-depleted (C) and (E) and IFT88-depleted (G) cells. Scale bars: $10 \mu \mathrm{m}$. The control cell (A) is covered in cilia, whereas the MKS3-depleted cells show sparse and short cilia (C) and (E). The IFT88-depleted cell (G) has almost no cilia remaining, although a few short cilia are visible (yellow arrows). Higher magnifications of the cell surfaces from (A), (C), (E) and (G) (yellow boxes) are shown in (B), (D), (F) and $(\mathbf{H})$, respectively (scale bars: $2 \mu \mathrm{m})$. Control cell surface (B) shows cilia arising from the cortical units, whereas the MKS3-depleted cells show short and missing cilia (D) and (F). Over 50\% of the MKS3-depleted cells have cilia that are severely misshapen and "blebby." The cell surfaces of these cells also became heavily wrinkled and distorted (F). The IFT88-depleted cell (H) shows normal organization of cortical units.

any of the control cells. The control cell in Figure $2 \mathrm{~A}$ is fixed with the metachronal wave intact, but the $M K S 3$ depleted cell shown in Figure $2 \mathrm{~B}$ is not, which is far more common. This difference between the two cells is not a consequence of the reduction of $M K S 3$ mRNA. The disturbance to the cell and cilia surface by reduction of $M K S 3$ mRNA is more evident at higher magnification (Figures 2D and 2F). We used RNAi to reduce mRNA for IFT88 that is known to cause loss of cilia by failure of intraflagellar transport (IFT), a mechanism that is specific to ciliary development and maintenance. The IFT88-depleted cells display a normally patterned cell surface (Figures $2 \mathrm{G}$ and $2 \mathrm{H}$ ), with very few and short cilia present on the surface of the majority of the cells (Figure 2G, yellow arrows).

MKS3 RNAi resulted in cells that appear, by SEM examination (Figure 2), to have missing or shortened cilia everywhere on the cell, except in the oral groove. For more details regarding short cilia, refer to Additional file 6. The reduction of $M K S 3$ using RNAi also caused 
severe distortions in the cell surface, in contrast to the surfaces of cells depleted of IFT88, which show missing cilia but no other disruptions.

Transmission electron microscopy (TEM) was employed to examine the ultrastructure of basal bodies to determine whether they were structurally equivalent in control and MKS3-depleted cells. The loss of cilia that we observed was not due to their inability to properly form basal bodies. Cross-sections of basal bodies observed using TEM were measured for both height and width using ImageJ software [31]. No differences were observed between control basal bodies, which were $379.6 \pm 42.4 \mathrm{~nm}$ in length and $202.9 \pm 22.8 \mathrm{~nm}$ in width $(n=13)$, and MKS3-depleted basal bodies, which were $367.7 \pm 35.5 \mathrm{~nm}$ long and $191.8 \pm$ $21.9 \mathrm{~nm}$ wide $(n=14)$. In addition, no obvious differences in basal body docking were observed.

\section{Immunofluorescence: basal bodies and cortical units}

Immunostaining of the MKS3-depleted cells with anticentrin revealed a basal body pattern that differed from that of the control and IFT88-depleted cells. The images shown in Figure 3 are stacks of Z-sections approximately $10 \mu \mathrm{m}$ thick, which we used to ensure all basal bodies could be visualized. The representative views shown are of the anterior dorsal surfaces of the cells. The control cell shows rows of basal bodies that run from anterior to posterior (Figure 3). The basal body rows at the midline of the typical MKS3-depleted cell show disorganization and twisting (Figure 3, white arrows). Distortions of rows can be seen elsewhere on the dorsal sides of the cells, but are most commonly observed at the dorsal midline. The control and IFT88-depleted cells maintain straight, organized rows.

In Figure 4, the ridges of the cortical units are highlighted using anti-2F12 at 60× magnification. Light staining of a basal body can be seen at the center of each unit. The dorsal surface of a control cell (Figure 4A) demonstrates the high level of organization of the cortical units. An area of the control cell has been enlarged (yellow box) to better highlight this surface (Figure 4a). The lower images in Figures $4 \mathrm{a}$ to $4 \mathrm{c}$ have been traced for clarity and are to the right of each image. The contractile vacuole pores are indicated by gray arrows. The two MKS3-depleted cells (Figures 4B and 4C) show two major types of differences from the control: an insertion of cortical units that incorporates a short row into another row of units (a kinety) (Figure 4B, yellow arrows) and clustering of basal bodies that should be organized in a row (Figure $4 \mathrm{C}$, yellow arrows). The MKS3-depleted cell with the insertion of an abbreviated kinety has a basal body for almost every cortical unit (Figure 4B), whereas the complete surface disruption, the clustering, shows chaotic organization of the cortical units, some of which are missing a basal body (Figure 4C). Of the MKS3-depleted cells, 70\% show kinety disruptions. Of those $70 \%, 90 \%$ had clusters of basal bodies, as shown in Figure $4 \mathrm{C}$, and $10 \%$ had an insertion of a partial kinety row, as shown in Figure 4B. These changes in ridge patterns were always observed on the dorsal surfaces of the cells, often near the midline and never at the extreme poles of the cell, in over 30 control and 70 MKS3depleted cells.

Each cortical unit has one or two basal bodies with corresponding microtubule rootlets. The transverse microtubule (TM) and the postciliary microtubule (PCMs) are oriented in 5 o'clock and 7 o'clock directions, with the anterior end of the cell pointing to 12 o'clock. We examined the orientation of TMs and PCMs using an anti- $\alpha$-tubulin antibody and the basal bodies using the Tetrahymena anti-centrin antibody. The MKS3-depleted cells lost most of their cilia, which facilitated the imaging of the basal bodies and the cortical microtubule cytoskeleton. However, the cilia on control cells obscured the image of the cortical microtubules that were visualized with the anti- $\alpha$-tubulin antibody. Therefore, we used IFT88depleted cells as a control because they lose their cilia but do not lose alignment of basal bodies in orderly rows of cortical units (Figure 3).
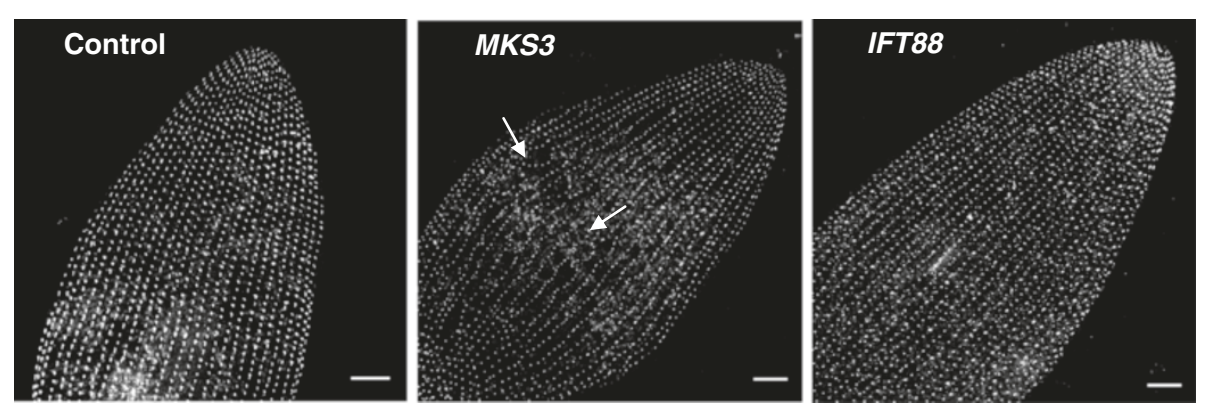

Figure 3 Basal bodies of $M K S 3$-depleted cells are misaligned primarily at the dorsal midline. Cells were stained using anti-centrin to visualize the basal bodies. Images represent stacks of Z sections approximately $10 \mu \mathrm{m}$ thick. The images shown are the dorsal surface of the anterior side of the cell. Basal bodies should be arranged in organized rows, as shown in the control and IFT88-depleted cells. The MKS3-depleted cell (center panel) shows the basal bodies not aligned and no longer in straight rows (white arrows) at the midline of the cell. Scale bars: $10 \mu \mathrm{m}$. 

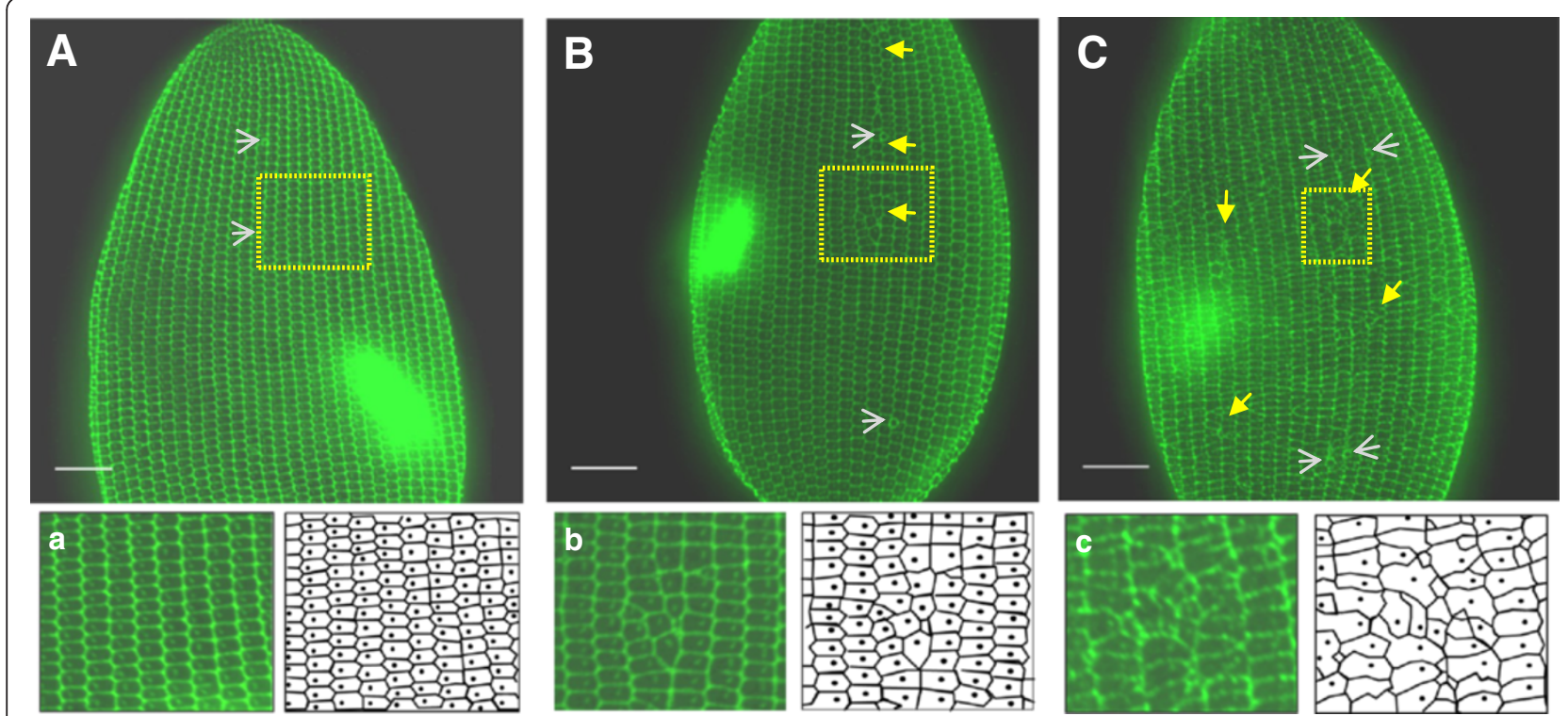

Figure 4 Disruptions of the cortical units correspond to the areas of basal body misalignment. Control (A) and MKS3-depleted cells (B) and (C) were stained using anti-2F12 to visualize the cortical ridges. These images show the dorsal surface and are stacks of Z sections approximately $10 \mu \mathrm{m}$ thick. The bright green immunofluorescence spots indicate the oral grooves. The control cell in (A) shows the high degree of organization of the outer lattice across the cell surface. The presence of a basal body in each unit can be seen in the enlarged area (A(a), yellow box) and the traced image below (black dot inside the hexagonal unit). The MKS3-depleted cells illustrate insertion of several cortical units forming an abbreviated kinety $(\mathbf{B}(\mathbf{b})$, yellow arrows) or a disruption type caused by the insertion of multiple cortical units, resulting in the formation of a cluster $(\mathbf{C}(\mathbf{c})$, yellow arrows). The contractile vacuole pores are indicated by gray arrows. Scale bars: $10 \mu \mathrm{m}$.

Figure 5 shows representatives of both IFT88-depleted cells (Figure 5A) and MKS3-depleted cells (Figure 5B). Basal bodies of the control IFT88-depleted cells showed organized rows and microtubule rootlets that maintained their polarity and orientation. In contrast, the representative MKS3-depleted cell showed twisting of a basal body row and with it a new alignment of the TM and PCM rootlets. The organized pattern of the IFT88-depleted cell is enlarged in Figure 5A (yellow box) and traced to show the basal bodies (red) and their microtubule rootlets (black). The same pattern is shown for the MKS3-depleted cell in Figure 5B (yellow box), where the orientation of the microtubule rootlets, as well as the basal bodies, can clearly be seen. The angle between the TM and PCM ribbons that emanate from the basal body was maintained in the MKS3-depleted cells (Figure 5C), but the orientation of the rootlets relative to the anteroposterior axis was changed. Both of the images of representative cells shown in Figure 5 are of the dorsal surfaces, and the enlarged areas are from near the dorsal midline. Note that the
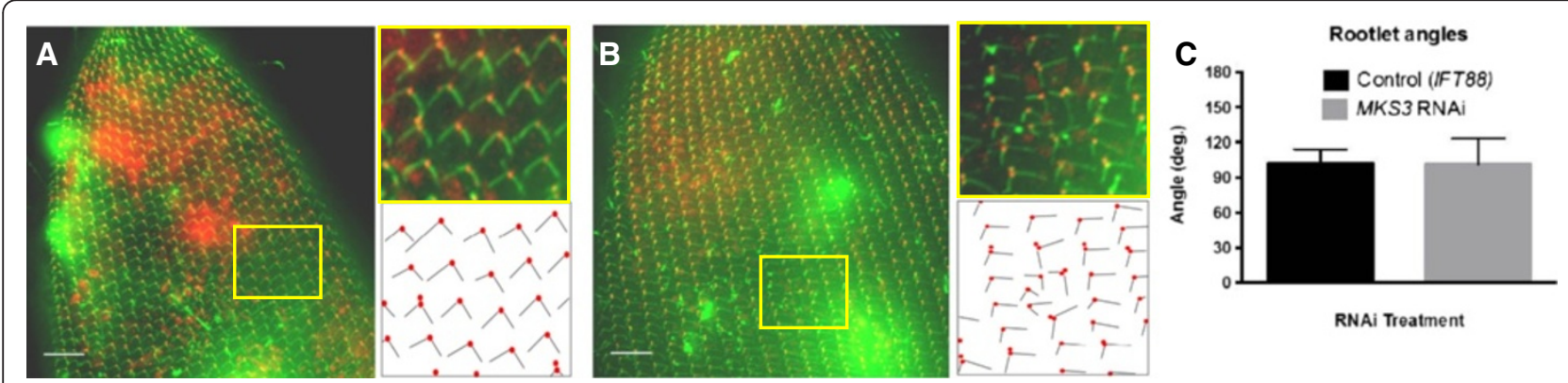

Figure $\mathbf{5}$ Microtubule ribbons have an altered orientation in MKS3 depleted cells. IFT88-depleted cells (A) and MKS3-depleted cells (B) cells were stained using anti-centrin basal bodies (red) and anti-tubulin microtubule rootlets (green). Images are stacks of $Z$ sections approximately $10 \mu \mathrm{m}$ thick. All images show the anterior dorsal surface. Areas in (A) and (B) (yellow box) have been enlarged, and below each is a tracing to depict the basal body (red) and the emanating rootlets (black). The rootlets are organized into the basal body rows (kineties) at 5 o'clock orientation (transverse microtubules (TMs)) and 7 o'clock orientation (postciliary microtubules (PCMs)) relative to the basal body. In the disrupted region of the MKS3-depleted cell (B), the microtubule rootlets are present and maintain the angle between them (C), but do not maintain the regular orientation along the anteroposterior cell axis as shown in the control cell. Scale bars: $10 \mu \mathrm{m}$. The angles between the TM and the PCM were measured (C), and these angles were maintained in the MKS3-depleted cells (35 cells from both test and control cells). Error bars are \pm SD. 
microtubule rootlet misalignments coincide with basal body misalignments, but not vice versa. The third rootlet, the striated rootlet (SR), also called the kinetodesmal fiber, was visualized using anti-KDF [37] and the basal bodies with anti-Glu- $\alpha$-tubulin.

Figure 6A shows a control RNAi-fed cell with basal bodies (red) forming clear, organized rows, or kineties, along the cell surface. Emanating from the left side of each basal body is a striated rootlet (green). These fibers extend toward the anterior pole of the cell and span two or more cortical units [19]. The control cell clearly demonstrates the anterior orientation of the SRs. In the case of two basal body units, this fiber projects only from the posterior of the basal body pair (Figure 6A, yellow arrows). The large red structures in Figures $6 \mathrm{~A}$ and $6 \mathrm{~B}$ are the contractile vacuoles and are not the subject of this study. In the MKS3-depleted cell within the areas of basal body misalignment, the SRs do not always project anteriorly and often veer in oblique directions (Figure 6B (b) and $\left.6 \mathrm{~B}\left(\mathrm{~b}^{\prime}\right)\right)$. The basal bodies are no longer maintained in their kinety rows, and, much like the twisted orientation of the PCMs and TMs shown in Figure 5, the SRs are chaotic in their orientations. These data, in conjunction with the TM and PCM data (Figure 5), suggest that these rootlets normally develop from the basal body, but the basal body has lost its orientation and does not maintain its position along the anteroposterior axis of the cell (see also Additional file 7: Figure S3).

\section{Mass spectrometry and potential interacting partners}

Whole-cell extract was collected from wild-type cells, solubilized and probed using either expressed GST or expressed GST fused with the coiled-coil domain of MKS3. Samples were separated on SDS-PAGE gels and silverstained, and the entire test (GST-MKS3 coiled-coil) and control (GST) lanes were analyzed by LC-MS/MS. We considered only those proteins unique to the test lane. In total, five proteins unique to the test sample were identified (Table 1). These proteins had a minimum of two unique peptides and included two Paramecium centrin-binding proteins (PtCenBP1), a sarcoendoplasmic reticulum calcium transport ATPase pump (PtSERCA1), a Ran-GTPase-activating protein and a kinetodesmal fiber protein (KdB2).
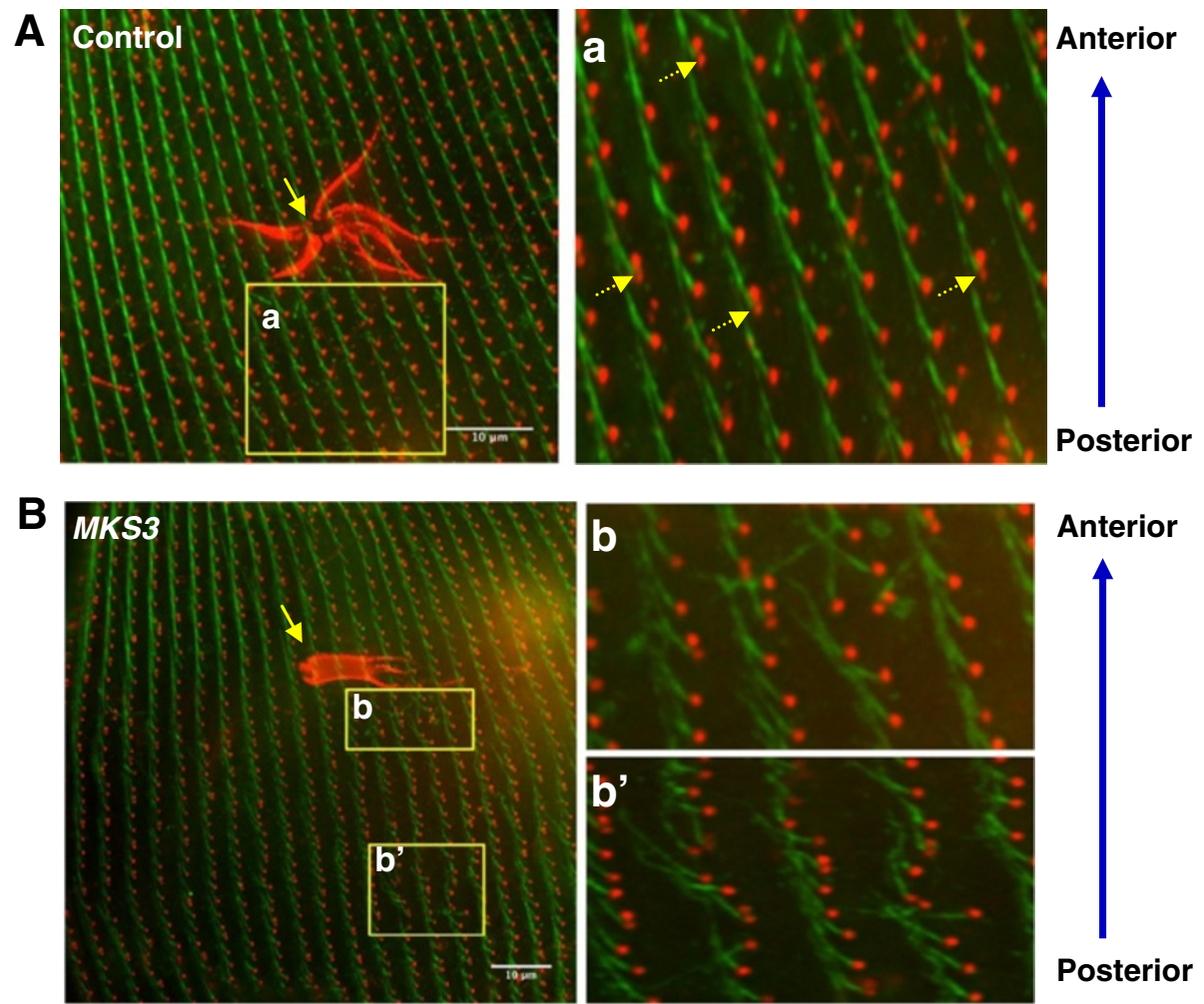

\section{Anterior}

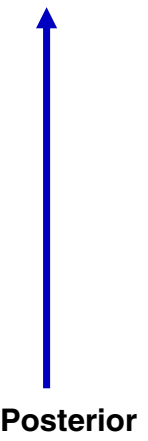

Figure $\mathbf{6}$ Chaotic orientation of the striated rootlet in MKS3-depleted cells. Control cells (A) and MKS3-depleted cells (B) were stained with anti-Glu-a-tubulin (red; basal bodies) and anti-kinetodesmal fibers (green; striated rootlets). Yellow arrows in (A) and (B) indicate the contractile vacuoles on the dorsal surface of these cells. Striated rootlets (SRs) project from the basal bodies. In two basal body units, SRs project only from the posterior basal body (a; dotted yellow arrows). SRs project toward the anterior of the cell in a highly organized manner along the kinety. Cells depleted of MKS3 depict chaotic organization of the SRs, which project in every direction ( $b$ and b'). Scale bar: $10 \mu \mathrm{m}$. 
Table 1 Unique proteins to the test lane from glutathione S-transferase-MKS3 coiled-coil domain pull-down

\begin{tabular}{ccccc}
\hline ParameciumDB accession number & Molecular weight & Peptides (control) & Peptides (test) & Name \\
\hline GSPATG00034434001 & $146 \mathrm{kDa}$ & 0 & 2 & PtCenBP1 \\
GSPATG00020240001 & $115 \mathrm{kDa}$ & 0 & 2 & PtSERCA1 \\
GSPATG00034433001 & $85 \mathrm{kDa}$ & 0 & 2 & PtCenBP1 \\
GSPATG00009639001 & $39 \mathrm{kDa}$ & 0 & 2 & Ran-GTPase-activating protein 1 \\
GSPATG00008129001 & $36 \mathrm{kDa}$ & 0 & 3 & KdB2 \\
\hline
\end{tabular}

\section{Discussion}

\section{Reduced MKS3 leads to abnormal and missing cilia}

We expressed FLAG-tagged MKS3 protein to localize it within the Paramecium cell and used feeding RNAi to explore for new functions of this protein. IFT88 served as a control for our approach because reduction of IFT88 mRNA would inhibit ciliary transport and help to determine whether short and missing cilia are sufficient to explain the RNAi phenotype for MKS3. Both IFT88and MKS3-depleted cells showed shortening and loss of cilia over the entire cell, except in the oral groove. These results for $M K S 3$ depletion are in agreement with those of Dawe et al. [27], who reported that small interfering RNA (siRNA) duplexes against $M K S 3$ caused short or missing cilia in inner medullary collecting duct cells (IMCD3). In the same study, siRNA duplexes were used against IFT88 in IMCD3 cells, leaving more than $90 \%$ of the cells without a primary cilium. The authors concluded that loss of MKS3 disrupts polarity of centrioles and their migration to the cell surface for ciliary formation [27]. Other studies have found a variety of changes in cilia numbers and length, possibly because of differences between cell types and methods of interfering with MKS3 expression through reduction in amount or mutation [27,38-41].

We found that aspects other than short and missing cilia differed between the Paramecium MKS3 RNAi phenotypes and IFT88 RNAi phenotypes. For example, the cilia that remained on the IFT88-depleted cells appeared short but not misshapen, whereas those on MKS3-depleted cells were short with bulging membranes, giving them a blebby appearance, especially at the tips.

In other systems, MKS3 (TMEM67) functions as part of the filter or as a gatekeeper in the transition zone, which is the region between the basal body and the ciliary necklace [13,42-44]. Failure of transition zone function to control ciliary structure and membrane composition can lead to short and bulbous cilia [45], which is similar to our observed blebby cilia on cells depleted of MKS3 by RNAi. Our immunofluorescence data of paramecia expressing FLAG-MKS3 suggest that FLAG-MKS3p is in the transition zone, which in Paramecium has been defined as an area that spans from the epiplasm to the base of the cilium below the ciliary necklace [25,26] (Figure 1 and Additional file 5: Movie S1). The antibody we used to label basal bodies recognizes Tetrahymena centrin 1, which is most homologous to Paramecium centrin 2 and stains the full length of the Paramecium basal body below the cell surface [24]. The transverse section through the surface of the cell shows anti-FLAG labeling for FLAG-MKS3 near the cell surface and at or above the distal end of the basal body. This location of MKS3p in P. tetraurelia is also consistent with the observations reported by Dawe et al. [27], who were the first to show the localization of MKS3p at the base of the primary cilium at the transition zone in IMCD3 and HEK293 cells transfected with N-terminal tagged proteins. Other groups have reported similar findings $[13,46]$.

We propose that the depletion of MKS3p from the transition zone accounts for the loss of cilia and blebbing of the membrane of the short remaining cilia by causing a failure of the transition zone to regulate ciliary structure and membrane composition. Our data also suggest the presence of MKS3p in the distal portion of the cilium (observed by Western blotting) (Additional file 2: Figure S1). The cilia for the Western blot preparations are severed from the cell body above the ciliary necklace, which means that if MKS3p is in the cilia, the proteins on the blot come from above the transition zone [47].

\section{New phenotypes of MKS3 mRNA depletion suggest interaction with basal body striated rootlets}

The repetitive stereotypical rows of cortical units of $P$. tetraurelia allowed us to identify subtle deviations due to reduction of MKS3p. RNAi for $M K S 3$ led to basal bodies out of kinety rows on the dorsal surface, mostly at the midline. The disorganized basal bodies were in patches, mostly in clusters or, less often, in small extra rows and with misshapen morphology of cortical ridges. These phenotypes were not seen in the IFT88-depleted cells, indicating that the shortening and loss of cilia are not sufficient to explain these changes in MKS3-depleted paramecia.

Cortical units across the surface of Paramecium contain either one or two basal bodies (mono- or dikinetids, respectively). In preparation for cell division, basal bodies duplicate and the cell must enlarge and elongate. This first stage of division involves the conversion of all dikinetids to monokinetids [21], with the exception of 
those in the invariant zones at the extreme anterior and posterior ends of the cells $[19,21]$. This conversion of dito monokinetids is the earliest stage in preparation for cell division, and, once complete, the cell will begin basal body duplication and formation of the fission furrow at the midline of the cell [21]. For both the conversion of di- to monokinetids and basal body duplication, where a new basal body is produced anterior to the parental basal body, the anterior basal bodies or the new basal bodies move away from the parental basal bodies using the SR as a guide, thus maintaining orderly rows $[19,21]$. Although basal bodies in all areas outside the invariant zones must duplicate for cell division, we did not observe a distortion of the kinety rows of basal bodies except on the dorsal side and primarily at the midline. Therefore, we propose that the MKS3 RNAi phenotype of disorientation of basal bodies and rootlet orientations that we observed is primarily due to failure of the anterior basal body of two basal body units to migrate appropriately along the SR and maintain a straight kinety row. The conversion from di- to monokinetids occurs prior to basal body duplication first on the dorsal surface of the cell, where a large number of randomly distributed dikinetids exist [20], and at the midline because the anterior movement occurs in advance of basal body duplication.

The posterior basal body in the dikinetid has a cilium and full complement of rootlets (TM, PCM and SR) projecting in stereotypical orientations. The anterior basal body of the pair has no cilium and only the transverse microtubules associated with it. In addition to the rootlets, a set of three cytoskeletal nodes link the basal bodies of a dikinetid to each other and to the SR [20,21].
While moving, the anterior basal body remains linked to the SR, which extends for two or more cortical units toward the anterior and appears to act as a guide that keeps the migrating basal bodies aligned with the cortical row. Once the anterior basal body has separated from the posterior basal body, it develops a PCM and SR in addition to its preexisting TM [21]. A schematic of this process is shown in Figure 7.

We propose that misguidance in the early movement of the anterior basal body of dikinetids can account for the observed RNAi phenotype of misalignments, primarily near the dorsal midline. We also propose that all newly forming basal bodies that also use the SR as a guide could require MKS3p for their attachment to the SR. We expect that only the errors in anterior basal body movements in the dikinetics are noticed in $M K S 3$ RNAidepleted cells because they occur early, before basal body duplication, and because cells stop growing and do not proceed further with basal body duplication and cell division. Indeed, these RNAi-treated cells stop growing after 24 hours of RNAi feeding (data not shown). This hypothesis of interaction of MKS3p with the SR is strongly supported by the results of a GST pull-down assay. Using the MKS3p coiled-coil domain as bait, we have identified a kinetodesmal fiber protein ( $\mathrm{KdB} 2$ : GSPATG00008129001).

MKS3p bait also pulls down two Paramecium centrin binding protein $1 \mathrm{~s}$ (PtCenBP1: GSPATG00034434001 and GSPATG00034433001), which have been shown to be the main components of the infraciliary lattice (ICL). The ICL is a contractile cortical cytoskeletal network that is nucleated from the basal body region $[48,49]$. An interaction of MKS3p and PtCenBP1 could help to stabilize the basal

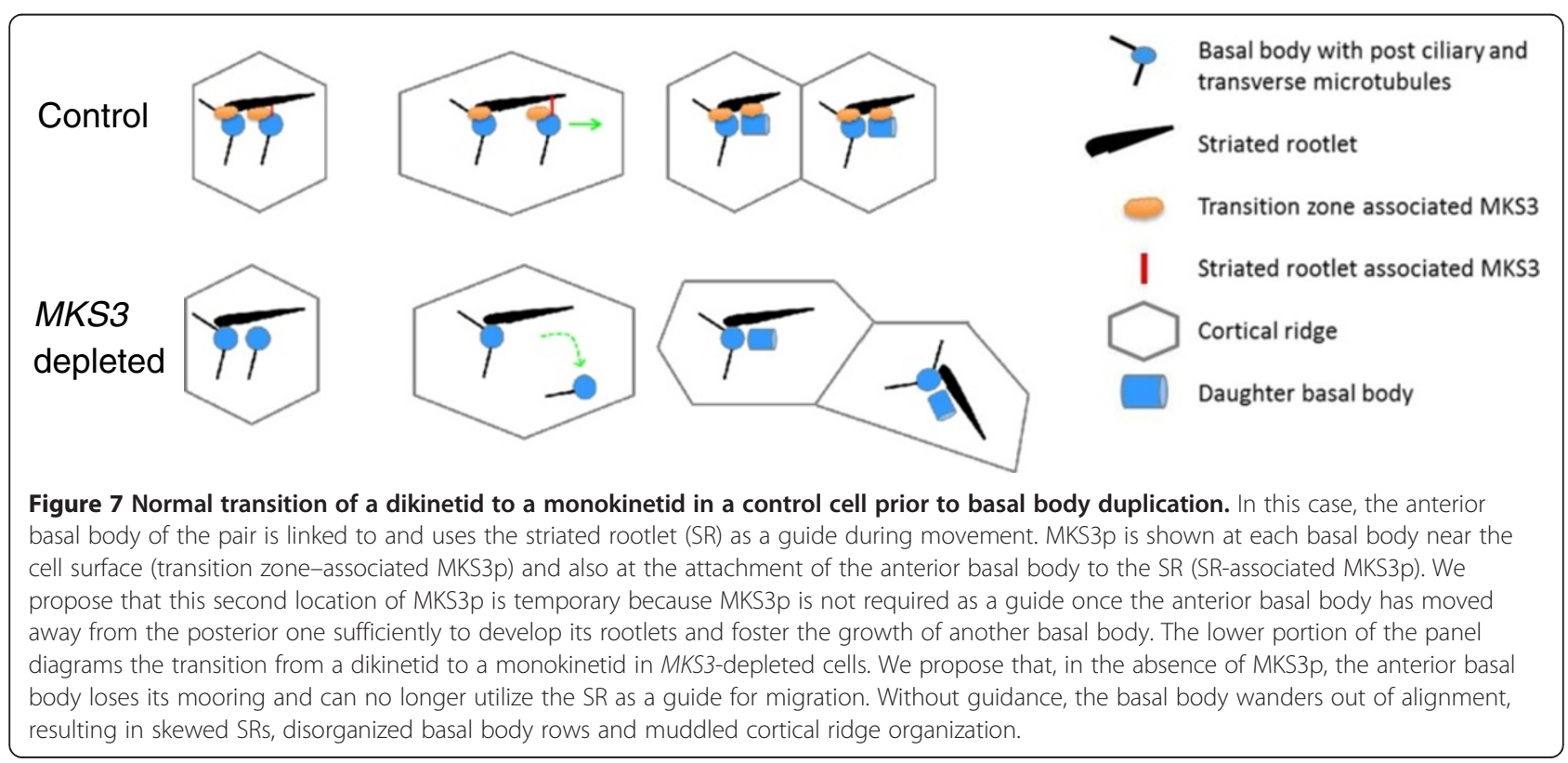


body within the cortical unit, allowing a cilium to be properly established.

GST pull-down results included Ran-GTPase-activating protein 1 (Ran-GAP:GSPATG00009639001). An interaction of RanGAP1 with MKS3p is interesting if the ciliary pore functions in a fashion similar to the nuclear pore complex, which has been suggested previously [50,51]. A Ran-GTPase/Ran-guanosine diphosphatase gradient between the ciliary and cellular compartments has been suggested to be involved in the entrance of select proteins such as Kif17 into the cilia in mammalian cells [52]. The interaction of MKS3p with RanGAP1 may prove to be a reflection of MKS3p function in the transition zone and part of the explanation for loss and deformation of cilia in MKS3 depletion.

It might be suggested that the misalignment phenotypes in MKS3-depleted cells is a result of inappropriate development of the SRs around the basal body. We do not favor this explanation, because in areas of disruption the PCM and TM form with a normal angle between them and KDFs develop. These results suggest that the entire basal body unit with its rootlets appears to be misdirected and not aligned with the anteroposterior axis of a kinety, as opposed to a dysfunction in SR development.

We did not identify a second location for MKS3 in our immunofluorescence studies of tagged MKS3p outside the transition zone. Although physical interactions of basal bodies and the SR were identified in structural studies [21], the transient nature of the attachments made it difficult to identify the interacting components. Our findings open up a new opportunity to dissect these transient but critical interactions.

\section{Conclusion}

There appear to be dual roles for MKS3 in Paramecium. First, we have shown that MKS3p in P. tetraurelia is located at the cell surface near each basal body's transition zone, where it most likely helps to filter and import (or retain) proteins into the cilia. When MKS3p from this location is reduced, cilia are lost and the cell surface and ciliary membranes become distorted. Second, a pool of MKS3 may be required in dikinetid units to guide the anterior basal body of the separating pair along the striated rootlet. A reduction in this pool of MKS3 may lead to the basal body becoming twisted and misaligned from its polarized row.

\section{Additional files}

Additional file 1: Table S1. Comparison of Paramecium intraflagellar transport 88 (IFT88) with other organisms. Table S2. Comparison of Paramecium meckelin (MKS3) with other organisms.
Additional file 2: Figure S1. Alignment of the full-length Paramecium mouse and human MKS3 amino acid sequences (A). (B) Cysteine-rich domain and coiled-coil domain show conservation across all species. The Paramecium cysteine-rich domain shows $23 \%$ identity to both the mouse and human sequences, and the majority of the cysteines in this region are conserved across all three species. The meckelin (MKS3) coiled-coil domain of Paramecium shows 59\% identity to the mouse MKS3 coiledcoil domain and 55\% identity to the human MKS3 coiled-coil domain. For all alignments, red indicates 100\% amino acid identity, green indicates an amino acid consensus match and white indicates a mismatch.

Additional file 3: Figure S2. Alignment of the full-length Paramecium, mouse and human intraflagellar transport 88 (IFT88) amino acid sequences (A). Four of the predicted tetratricopeptide repeat (TPR) domains of IFT88 are conserved in the Paramecium sequence (B). TPR1 shows $44 \%$ and $42 \%$ identity, TPR2 shows $45 \%$ and $51 \%$ identity, TPR3 shows 54\% and 53\% identity and TPR4 shows $43 \%$ and $44 \%$ identity to the mouse and human TPR domains, respectively. For all alignments, red indicates 100\% amino acid identity, green indicates an amino acid consensus match and white indicates a mismatch.

Additional file 4: Figure S4. To help determine the localization of this protein, we examined its presence in isolated whole cilia and pure cell (pellicle) membrane from cells expressing FLAG-MKS3 or, as a control, FLAG. The isolated proteins were then separated on SDS-PAGE gels and transferred to a nitrocellulose membrane. The nitrocellulose blots were then probed using anti-FLAG or anti-tubulin (loading control). The FLAGMKS3 protein can be seen at $105 \mathrm{kDa}$ in the cell membrane and at 105 and $77 \mathrm{kDa}$ in the whole cilia (blue arrows in Figure $1 \mathrm{C}$ in the main text). There are nonspecific bands present in both the test and control lanes in the whole cilia blot (gray arrows in Figure $1 \mathrm{C}$ in the main text; approximately $107 \mathrm{kDa}$ ) due to the large amount of protein loaded $(250 \mu \mathrm{g})$. Western blots developed with anti-FLAG of cell membrane and whole cilia show the FLAG-MKS3 protein in the cell membrane (blue arrowhead; approximately $105 \mathrm{kDa}$ ) and cilia (blue arrowheads; 105 and $77 \mathrm{kDa}$ ). Nonspecific bands present in both the test and control lanes are indicated by gray arrows. A representative anti-tubulin loading control blot is also shown.

Additional file 5: Movie S1. FLAG-MKS3-injected cell shown in Figure 1 in the main text begins outside the cell, with its anterior side on the right. As the movie plays, each frame is one z-section, showing the FLAG stain (green) in the frame before the centrin stain (red). Notice that the FLAG stain appears before (above) the basal bodies, which are positioned slightly below the membrane, and is positioned to the side and posteriorly.

Additional file 6: Cells depleted of IFT88 and MKS3 were compared to cells fed the empty RNAi vector (L4440) and immunostained with anti-tubulin (Sigma-Aldrich, St Louis, MO, USA) at a 1:200 dilution as described in Materials and methods. Cilia were measured using the DeltaVision microscopy system and softWoRx Pro software and compared using Student's $t$-test. We measured the remaining cilia on the surfaces of three cells of each type (control and IFT88- and MKS3-depleted). Those cilia remaining on the MKS3- and IFT88-depleted cells were significantly shorter than the control cilia ( $P<0.0001$ by Student's $t$-test). The MKS3and IFT88-depleted cells had average cilia lengths of $3.7 \pm 0.1 \mu \mathrm{m}$ ( $n=412$ cilia) and $3.7 \pm 0.2 \mu \mathrm{m}$ ( $n=279$ cilia), respectively, compared to the control cells, whose cilia were $9.7 \pm 0.1 \mu \mathrm{m}(n=191$ cilia).

Additional file 7: Figure S3. Images of control and MKS3 RNAi cells stained with anti-kinetodesmal fiber (anti-KDF) (green) and anti-Glu- $a-$ tubulin (red) show a larger section of the dorsal surface. Normal kinety and KDF alignment can be seen across the entire surface of the control cell. The MKS3-depleted cell shows clustering disruptions in multiple regions of the dorsal surface (yellow arrows).

\section{Abbreviations}

AMP: Ampicillin; DIC: Differential interference contrast; ER: Endoplasmic reticulum; EGTA: Ethyleneglycoltetraacetic acid; HEK293: Human embryonic kidney 293 cell line; HEPES: 2-[4-(2-hydroxyethyl)piperazin-1-yl]ethanesulfonic acid; IMCD3: Inner medullary collecting duct cell line; IFT: Intraflagellar transport; IPTG: Isopropyl- $\beta$-D-thiogalactopyranoside; MKS3: Meckelin; MKS: Meckel-Gruber syndrome; PCM: Postciliary microtubule; RNAi: RNA interference; SEM: Scanning electron microscopy; SD: Standard deviation; 
SR: Striated rootlet or kinetodesmal fiber; STDEM: Standard error of the mean; TEM: Transmission electron microscopy; TM: Transverse microtubule.

\section{Competing interests}

The authors declare that they have no competing interests.

\section{Authors' contributions}

TP was responsible for the anti-2F12, anti-KDF and tubulin rootlet immunostaining data and diagrams; GST-MKS3 coiled-coil domain construct creation, expression and pull-down; LC-MS/MS analysis, figure preparation, organization, preparation and critical reading of manuscript; and project and experiment design. MSV was responsible for the creation of the IFT88 RNAi plasmid and FLAG-MKS3 plasmid, basal body staining, FLAG-MKS3 protein localization, SEM, TEM, database searches, manuscript preparation, figure preparation, statistical analysis and experiment and project design. JY was responsible for all plasmid injections, experiment guidance and project design and critical reading of manuscript. JVH was the Principal Investigator for the project and was responsible for experiment and project design and preparation and critical reading of the manuscript. All authors read and approved the final manuscript.

\section{Acknowledgements}

We thank Jean Cohen and France Koll for the MKS3 RNAi plasmid and the anti-2F12 antibody, Janine Beisson for the anti-KDF antibody and Joel Rosenbaum for his critical suggestions and discussion of the manuscript. At the University of Vermont, Todd Clason of the imaging center at the Center of Biomedical Research Excellence with the DeltaVision Microscope; Michele von Turkovich for her assistance with SEM, TEM and critical point drying of samples; Jan Schwarz for assistance with TEM and to Dr. Mark Winey for donation of the Anti-centrin antibody. We also thank Julia Fields for her assistance with the LC-MS/MS sample preparation and analysis. The project described herein was supported, in part, by: Institutional Development Award (IDeA) from the National Institute of General Medical Sciences (NIGMS) of the National Institutes of Health (NIH) under grant number 9P20GM103449; NIH IDeA Grant Numbers 5 P30 RR032135 from the National Center for Research Resources and P30 GM 103498 from NIGMS; NIH NIGMS R01 GM59988.

\section{Received: 22 May 2013 Accepted: 7 January 2014} Published: 31 Jan 2014

\section{References}

1. D'Angelo A, Franco B (2009) The dynamic cilium in human diseases. Pathogenetics 2:3

2. Pazour GJ, Dickert BL, Vucica Y, Seeley ES, Rosenbaum JL, Witman GB, Cole DG (2000) Chlamydomonas IFT88 and its mouse homologue, polycystic kidney disease gene $\mathrm{Tg} 737$, are required for assembly of cilia and flagella. J Cell Biol 151:709-718

3. Pedersen $L B$, Rosenbaum $J \mathrm{~L}$ (2008) Intraflagellar transport (IFT) role in ciliary assembly, resorption and signalling. Curr Top Dev Biol 85:23-61

4. Sharma N, Berbari NF, Yoder BK (2008) Ciliary dysfunction in developmental abnormalities and diseases. Curr Top Dev Biol 85:371-427

5. Leitch CC, Zaghloul NA, Davis EE, Stoetzel C, Diaz-Font A, Rix S, Al-Fadhel M, Lewis RA, Eyaid W, Banin E, Dollfus H, Beales PL, Badano JL, Katsanis N (2008) Hypomorphic mutations in syndromic encephalocele genes are associated with Bardet-Biedl syndrome. Nat Genet 40:443-448

6. Brancati F, lannicelli M, Travaglini L, Mazzotta A, Bertini E, Boltshauser E, D’Arrigo S, Emma F, Fazzi E, Gallizzi R, Gentile M, Loncarevic D, Mejaski-Bosnjak V, Pantaleoni C, Rigoli L, Salpietro CD, Signorini S, Stringini GR, Verloes A, Zabloka D, Dallapiccola B, Gleeson JG, Valente EM, International JSRD Study Group (2009) MKS3/TMEM67 mutations are a major cause of COACH syndrome, a Joubert syndrome related disorder with liver involvement. Hum Mutat 30:E432-E442

7. Gleeson JG, Keeler LC, Parisi MA, Marsh SE, Chance PF, Glass IA, Graham JM Jr, Maria BL, Barkovich AJ, Dobyns WB (2004) Molar tooth sign of the midbrain-hindbrain junction: occurrence in multiple distinct syndromes. Am J Med Genet A 125A:125-134

8. Baala L, Romano S, Khaddour R, Saunier S, Smith UM, Audollent S, Ozilou C, Faivre L, Laurent N, Foliguet B, Munnich A, Lyonnet S, Salomon R, Encha-Razavi F, Gubler MC, Boddaert N, de Lonlay P, Johnson CA, Vekemans M, Antignac C, Attié-Bitach T (2007) The Meckel-Gruber syndrome gene, MKS3, is mutated in Joubert syndrome. Am J Hum Genet 80:186-194
9. Salonen R, Norio R (1984) The Meckel syndrome in Finland: epidemiologic and genetic aspects. Am J Med Genet 18:691-698

10. Salonen R, Paavola P (1998) Meckel syndrome. J Med Genet 35:497-501

11. Holmes LB, Driscoll SG, Atkins L (1976) Etiologic heterogeneity of neural-tube defects. N Engl J Med 294:365-369

12. Chen CP (2007) Meckel syndrome: genetics, perinatal findings, and differential diagnosis. Taiwan J Obstet Gynecol 46:9-14

13. Williams CL, Li C, Kida K, Inglis PN, Mohan S, Semenec L, Bialas NJ, Stupay RM, Chen N, Blacque OE, Yoder BK, Leroux MR (2011) MKS and NPHP modules cooperate to establish basal body/transition zone membrane associations and ciliary gate function during ciliogenesis. J Cell Biol 192:1023-1041

14. Allen RD, Fok AK (1980) Membrane recycling and endocytosis in Paramecium confirmed by horseradish peroxidase pulse-chase studies. J Cell Sci 45:131-145

15. Flötenmeyer M, Momayezi M, Plattner H (1999) Immunolabeling analysis of biosynthetic and degradative pathways of cell surface components (glycocalyx) in Paramecium cells. Eur J Cell Biol 78:67-77

16. Plattner $\mathrm{H}$, Kissmehl R (2003) Molecular aspects of membrane trafficking in Paramecium. Int Rev Cytol 232:185-216

17. Sonneborn TM (1970) Gene action in development. Proc R Soc Lond B Biol Sci 176:347-366

18. Allen RD (1971) Fine structure of membranous and microfibrillar systems in the cortex of Paramecium caudatum. J Cell Biol 49:1-20

19. Iftode F, Cohen J, Ruiz F, Torres Rueda A, Chen-Shan L, Adoutte A, Beisson J (1989) Development of surface pattern during division in Paramecium. I. Mapping of duplication and reorganization of cortical cytoskeletal structures in the wild type. Development 105:191-211

20. Iftode F, Adoutte A, Fleury A (1996) The surface pattern of Paramecium tetraurelia in interphase: an electron microscopic study of basal body variability, connections with associated ribbons and their epiplasmic environment. Eur J Protistol 32(Suppl 1):46-57

21. Iftode F, Fleury-Aubusson A (2003) Structural inheritance in Paramecium: ultrastructural evidence for basal body and associated rootlets polarity transmission through binary fission. Biol Cell 95:39-51

22. Beisson J, Sonneborn TM (1965) Cytoplasmic inheritance of the organization of the cell cortex in Paramecium aurelia. Proc Natl Acad Sci U S A 53:275-282

23. Ruiz F, Beisson J, Rossier J, Dupuis-Williams P (1999) Basal body duplication in Paramecium requires $\gamma$-tubulin. Curr Biol 9:43-46

24. Ruiz F, Garreau de Loubresse N, Klotz C, Beisson J, Koll F (2005) Centrin deficiency in Paramecium affects the geometry of basal-body duplication. Curr Biol 15:2097-2106

25. Aubusson-Fleury A, Lemullois M, Garreau de Loubresse N, Laligné C, Cohen J, Rosnet O, Jerka-Dziadosz M, Beisson J, Koll F (2012) The conserved centrosomal protein FOR20 is required for assembly of the transition zone and basal body docking at the cell surface. J Cell Sci 125:4395-4404

26. Dute R, Kung C (1978) Ultrastructure of the proximal region of somatic cilia in Paramecium tetraurelia. J Cell Biol 78:451-464

27. Dawe HR, Smith UM, Cullinane AR, Gerrelli D, Cox P, Badano JL, Blair-Reid S, Sriram N, Katsanis N, Attié-Bitach T, Afford SC, Copp AJ, Kelly DA, Gull K, Johnson CA (2007) The Meckel-Gruber syndrome proteins MKS1 and meckelin interact and are required for primary cilium formation. Hum Mol Genet 16:173-186

28. Sasner JM, van Houten JL (1989) Evidence for a Paramecium folate chemoreceptor. Chem Senses 14:587-595

29. Wright MV, van Houten $J \mathrm{~L}$ (1990) Characterization of a putative $\mathrm{Ca}^{2}$ ${ }^{+}$-transporting $\mathrm{Ca}^{2+}$-ATPase in the pellicles of Paramecium tetraurelia. Biochim Biophys Acta 1029:241-251

30. Adoutte A, Ramanathan R, Lewis RM, Dute RR, Ling KY, Kung C, Nelson DL (1980) Biochemical studies of the excitable membrane of Paramecium tetraurelia. III. Proteins of cilia and ciliary membranes. J Cell Biol 84:717-738

31. Rasband WS (1997-2014) ImageJ [software]. National Institutes of Health, Bethesda, MD, Available at http://imagej.nih.gov/ij/index.html (accessed 13 January 2014)

32. Lieberman SJ, Hamasaki T, Satir P (1988) Ultrastructure and motion analysis of permeabilized Paramecium capable of motility and regulation of motility. Cell Motil Cytoskeleton 9:73-84

33. Saha M, Carriere A, Cheerathodi M, Zhang X, Lavoie G, Rush J, Roux PP, Ballif BA (2012) RSK phosphorylates SOS1 creating 14-3-3-docking sites and negatively regulating MAPK activation. Biochem J 447:159-166 
34. Valentine MS, Rajendran A, Yano J, Weeraratne SD, Beisson J, Cohen J, Koll F, Van Houten J (2012) Paramecium BBS genes are key to presence of channels in cilia. Cilia 1:16

35. Li H, Durbin R (2009) Fast and accurate short read alignment with Burrows-Wheeler transform. Bioinformatics 25:1754-1760

36. Galvani A, Sperling L (2002) RNA interference by feeding in Paramecium. Trends Genet 18:11-12

37. Sperling L, Keryer G, Ruiz F, Beisson J (1991) Cortical morphogenesis in Paramecium: a transcellular wave of protein phosphorylation involved in ciliary rootlet disassembly. Dev Biol 148:205-218

38. Cook SA, Collin GB, Bronson RT, Naggert JK, Liu DP, Akeson EC, Davisson MT (2009) A mouse model for Meckel syndrome type 3. J Am Soc Nephrol 20:753-764

39. Tammachote R, Hommerding CJ, Sinders RM, Miller CA, Czarnecki PG, Leightner AC, Salisbury JL, Ward CJ, Torres VE, Gattone VH 2nd, Harris PC (2009) Ciliary and centrosomal defects associated with mutation and depletion of the Meckel syndrome genes MKS1 and MKS3. Hum Mol Genet 18:3311-3323

40. Smith UM, Consugar M, Tee L, McKee BM, Maina EN, Whelan S, Morgan NV Goranson E, Gissen P, Lilliquist S, Aligianis IA, Ward CJ, Pasha S, Punyashthiti R, Sharif SM, Batman PA, Bennett CP, Woods CG, McKeown C, Bucourt M, Miller CA, Cox P, Al-Gazali L, Trembath RC, Torres VE, Attie-Bitach T, Kelly DA Maher ER, Gattone VH 2nd, Harris PC, Johnson CA (2006) The transmembrane protein meckelin (MKS3) is mutated in Meckel-Gruber syndrome and the wpk rat. Nat Genet 38:191-196

41. Dawe HR, Adams M, Wheway G, Szymanska K, Logan CV, Noegel AA, Gull K, Johnson CA (2009) Nesprin-2 interacts with meckelin and mediates ciliogenesis via remodelling of the actin cytoskeleton. J Cell Sci 122:2716-2726

42. Czarnecki PG, Shah JV (2012) The ciliary transition zone: from morphology and molecules to medicine. Trends Cell Biol 22:201-210

43. Chih B, Liu P, Chinn Y, Chalouni C, Komuves LG, Hass PE, Sandoval W, Peterson AS (2012) A ciliopathy complex at the transition zone protects the cilia as a privileged membrane domain. Nat Cell Biol 14:61-72

44. Garcia-Gonzalo FR, Reiter JF (2012) Scoring a backstage pass: mechanisms of ciliogenesis and ciliary access. J Cell Biol 197:697-709

45. Garcia-Gonzalo FR, Corbit KC, Sirerol-Piquer MS, Ramaswami G, Otto EA, Noriega TR, Seol AD, Robinson JF, Bennett CL, Josifova DJ, García-Verdugo JM, Katsanis N, Hildebrandt F, Reiter JF (2011) A transition zone complex regulates mammalian ciliogenesis and ciliary membrane composition. Nat Genet 43:776-784

46. Adams M, Simms RJ, Abdelhamed Z, Dawe HR, Szymanska K, Logan CV, Wheway G, Pitt E, Gull K, Knowles MA, Blair E, Cross SH, Sayer JA, Johnson CA (2012) A meckelin-filamin A interaction mediates ciliogenesis. Hum Mol Genet 21:1272-1286

47. Satir B, Sale WS, Satir P (1976) Membrane renewal after dibucaine deciliation of Tetrahymena: freeze-fracture technique, cilia, membrane structure. Exp Cell Res 97:83-91

48. Beisson J, Clérot JC, Fleury-Aubusson A, Garreau de Loubresse N, Ruiz F Klotz C (2001) Basal body-associated nucleation center for the centrin-based cortical cytoskeletal network in Paramecium. Protist 152:339-354

49. Gogendeau D, Beisson J, Garreau de Loubresse N, Le Caer JP, Ruiz F, Cohen J, Sperling L, Koll F, Klotz C (2007) An Sfilp-like centrin-binding protein mediates centrin-based $\mathrm{Ca}^{2+}$-dependent contractility in Paramecium tetraurelia. Eukaryot Cell 6:1992-2000

50. Kee HL, Verhey KJ (2013) Molecular connections between nuclear and ciliary import processes. Cilia 2:11

51. Fan S, Margolis B (2011) The Ran importin system in cilia trafficking. Organogenesis 7:147-153

52. Dishinger JF, Kee HL, Jenkins PM, Fan S, Hurd TW, Hammond JW, Truong YN, Margolis B, Martens JR, Verhey KJ (2010) Ciliary entry of the kinesin-2 motor KIF17 is regulated by importin- $\beta 2$ and RanGTP. Nat Cell Biol 12:703-710

10.1186/2046-2530-3-2

Cite this article as: Picariello et al: Reduction of meckelin leads to general loss of cilia, ciliary microtubule misalignment and distorted cell surface organization. Cilia 2014, 3:2

\section{Submit your next manuscript to BioMed Central and take full advantage of:}

- Convenient online submission

- Thorough peer review

- No space constraints or color figure charges

- Immediate publication on acceptance

- Inclusion in PubMed, CAS, Scopus and Google Scholar

- Research which is freely available for redistribution

Submit your manuscript at www.biomedcentral.com/submit 